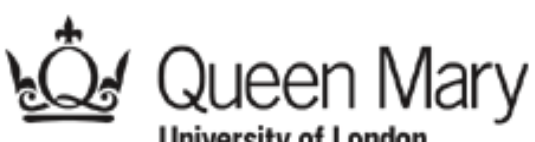 \\ University of London
}

\section{Centre Ior Globalisation Research}

School of Business and Management

\section{Does inequality foster or hinder the growth of}

\author{
entrepreneurship in the long-run?
}

CGR Working Paper 83

\section{Roxana Gutiérrez-Romero and Luciana Méndez Errico}

\begin{abstract}
This article assesses the extent to which historical levels of inequality affect the creation and survival of businesses over time. To this end, we use the Global Entrepreneurship Monitor (GEM) survey across 66 countries over 2005-2011. We complement this survey with data on income inequality dating back to early 1800 s and current institutional environment, such as the number of procedures to start a new business, countries' degree of financial inclusion, corruption and political stability. We find that although inequality increases the number of firms created out of need, inequality reduces entrepreneurial activity as in net terms businesses are less likely to be created and survive over time. These findings are robust to using different measures of inequality across different points in time and regions, even if excluding Latin America the most unequal region in the world. Our evidence then supports theories that argue early conditions, crucially inequality, influence development path.
\end{abstract}

Keywords: Inequality; entrepreneurship; panel data; instrumental variables.

JEL codes: M2; O1; D3; C23. 


\title{
Does inequality foster or hinder the growth of entrepreneurship in the long-run?*
}

\author{
Roxana Gutiérrez-Romero • and Luciana Méndez-Errico ${ }^{ \pm}$
}

\begin{abstract}
This article assesses the extent to which historical levels of inequality affect the creation and survival of businesses over time. To this end, we use the Global Entrepreneurship Monitor (GEM) survey across 66 countries over 2005-2011. We complement this survey with data on income inequality dating back to early 1800s and current institutional environment, such as the number of procedures to start a new business, countries' degree of financial inclusion, corruption and political stability. We find that although inequality increases the number of firms created out of need, inequality reduces entrepreneurial activity as in net terms businesses are less likely to be created and survive over time. These findings are robust to using different measures of inequality across different points in time and regions, even if excluding Latin America the most unequal region in the world. Our evidence then supports theories that argue early conditions, crucially inequality, influence development path.
\end{abstract}

Keywords: Inequality; entrepreneurship; panel data; instrumental variables.

JEL Codes: M2, O1, D3, C23.

\footnotetext{
${ }^{*}$ We thank Fabrice Murtin for having shared with us the historical estimators on income distribution shown in this chapter. We thank Isabel Busom, Cristina López-Mayan, Adam Pepelasis, Xavi Ramos, Francesc Trillas and the participants of the EDIE workshop, the GEM-Barcelona conference,
} UAB PhD seminar, Universidad Tecnológica Metropolitana de Mérida, the LACEA/IADB/WB/UNDP Research Network of Inequality and Poverty for their comments and suggestions on earlier drafts of this chapter. We acknowledge financial support from the Spanish Ministry of Science and Innovation (reference ECO2010-21668-C03-02 and ECO2013-46516-C41-R), and from the Generalitat of Catalunya (reference 2014SGR-1279).

- Corresponding author: Queen Mary, University of London, School of Business and Management, London, E1 4NS, UK. Email: r.gutierrez@qmul.ac.uk

${ }^{ \pm}$Universidad Autónoma de Barcelona, Building B, Department of Applied Economics, Bellaterra, 08193, Spain. 


\section{Introduction}

The old debate on whether inequality affects long-run development has received renewed attention, particularly since inequality has been rising in recent decades (Piketty, 2015). A substantial theoretical literature has, in turn, analysed whether inequality has any long-lasting effects particularly on entrepreneurial activities. Entrepreneurship has long been argued to be one of the main contributors to economic development given its role in job creation, introducing technological innovation, increasing value added and per capita incomes over time (Audretsch et al., 2006; Baumol et al., 2007; Schumpeter, 1943). In this respect, some studies have argued that higher inequality can have a detrimental effect on entrepreneurship if a large proportion of individuals are prevented from taking up profitable investments. It is argued that this negative and long-lasting effect gets exacerbated whenever accompanied by credit market imperfections (Banerjee and Newman, 1993; Ghatak and Jiang, 2002). There are other studies that instead predict inequality has a positive effect on entrepreneurship. For instance, if the investments made by wealthy people increases the funds available in the economy, the poor then could benefit from the so-called "trickle-down" effect (Aghion and Bolton, 1997). The literature has also pointed out the possibility that inequality could well have null effects, for instance whenever the volatility of returns to occupations outweighs the role that wealth distribution might play (Champernowne, 1953).

The ambiguity of the theoretical predictions is reflected in the very mixed findings of the empirical literature. Some studies suggest that inequality has either a positive or a negative effect on economic growth, whilst others finding no effect at all (Bénabu, 1996; Cingano, 2014; De Dominicis et al., 2006; Voitchovsky, 2009). Empirical studies looking more specifically at the impact of inequality on entrepreneurial rates are scant. Although there are some international cross-country studies, these efforts have primarily provided simple correlations without testing (and correcting) for the likely presence of endogeneity between inequality and 
entrepreneurial rates. The lack of robust evidence thus limits our understanding of the effects that inequality might have (Lecuna, 2014; Lippman et al., 2005; Reynolds et al., 2005).

The objective of this article is to empirically test whether income inequality has a longterm effect on entrepreneurship. Specifically, the article offers two contributions. First, unlike much of previous empirical studies, we directly test whether income inequality that prevailed in the distant past, dating back to early 1800s, has any effect on contemporaneous entrepreneurial activity across 66 countries over 2005-2011. Since inequality might have a non-linear effect over time, we use different inequality measures, and over different periods (1820, 1910 and 1980). This approach allows us to overcome some of the issues pointed out by Piketty and Saez (2006), who argue that in order to understand the causes and consequences of changes in income and wealth distribution one needs to put them in a broad historical perspective. Second, we assess the impact that inequality has broadly on different stages of entrepreneurship by analysing: start-ups, established businesses, as well as those businesses that were opened out of need. By separately studying the association between historical inequality and these different entrepreneurial activities, we are able to provide a broader picture as to how inequality might affect the creation and survival of businesses. For instance, previous studies have shown that Latin America, the most unequal region in the world, has a positive correlation between contemporaneous indicators of income inequality and the number of enterprises being created. However, many of these enterprises do not survive over time given that some of these businesses were opened out of need (as people had no other job options, or due to the poor economic conditions of the country). Hence, it is important to analyse the impact that inequality has on the number of established enterprises and on those that were created for reasons other than seeking-pure profits.

To study the relationship between inequality and entrepreneurship we use the Global Entrepreneurship Monitor (GEM) survey. GEM is the largest survey of entrepreneurial activity 
around the globe, drawing nationally representative surveys on entrepreneurial activity on an annual basis. We complement this survey with historical estimates of income distribution ranging from the 19th century until the 20th century as estimated by Bourguignon and Morrison (2002). In addition to past inequality indicators, we also consider contemporaneous institutional factors that could affect the creation and maturity of firms according to the literature. These refer to a number of procedures to start a new business, access to formal credit and indicators of good governance such as the degree of country's political stability and control of corruption (La Porta et al., 1998; Naudé, 2008; Perotti, 1996). In contrast to previous similar studies, we address for the likely endogeneity that might be present when considering the impact of these institutional variables on entrepreneurship (e.g. Alvarez and Urbano, 2011; Lecuna, 2014). We do so given that these institutional variables could be endogenously determined by the proportion of people involved in entrepreneurial activities who, for instance, may lobby for lower business start costs, more financial access, better governance, etc. To this end, we use instrumental variables (IV), a method commonly to deal with endogeneity. ${ }^{2}$

\footnotetext{
${ }^{2}$ As instruments, we include those shown in previous literature to be strongly correlated with the institutional variables considered. Thus, number of procedures to start a new business, control of corruption and political stability are instrumented with the colonial origin of the country and the European settler mortality rate (Acemoglu et al., 2001) and the number of journalist killed by country (Besley and Burgess, 2001; Besley and Prat, 2006; Chowdhury, 2004). We also instrument financial inclusion with the fixed telephone subscriptions per 100 people (Beck et al., 2007) and other indicators found in the literature as associated with the biological responses that people suffer due to experiencing financial hardship such as high systolic blood pressure (O’Neil et al., 2005) and high cholesterol levels, both indicators aggregated at country level (Ezzati et al., 2005). The various robustness tests confirm that all instruments are jointly correlated with the endogenous variables and to be valid instruments.
} 
Several articles before ours have found quite mixed evidence on the impact that inequality has on development, and specifically on entrepreneurship. Our findings help reconcile and understand this previous mixed evidence. On the one hand, we find countries that started with high levels of inequality in the early 1800s currently are more likely to have a higher number of enterprises created out of need. However, in net terms inequality overall has a detrimental effect on net entrepreneurial activity in both start-ups and established businesses (those businesses that have survived over 3.5 years), even when considering current business and institutional environment. This detrimental effect is consistent if analysing different inequality measures, across different points in time, and if analysing the entire 66 countries together, considering only the Global South (Africa, Asia and Latin America), or excluding Latin America. Our results are also robust if using instrumental variables.

We also find a strong association between the historical inequality indicators used and the contemporaneous differences in access to credit markets between the rich and poor. These findings give support to the common assumption in the theoretical literature that suggests income inequality reflects the severity of credit constraints people face (Ljungqvist, 1993). This evidence also gives evidence to the extent that inequality in the distant past has prevented the poorest and credit-constrained people investing in profitable activities, thereby reinforcing inequality patterns and dampening entrepreneurial activities over time (Banerjee and Newman, 1993).

Our results thus challenge those studies that argue entrepreneurship can be a ladder through which social mobility can take place given that the enterprises that get opened out of need are unlikely to survive in the long- or even medium-term (Solimano, 2014). Overall our results support theories that recommend wealth-distribution efforts and improved financial inclusion as means to foster entrepreneurship and development. If no such public interventions 
are taken, entrepreneurial activities in highly unequal countries are unlikely to render a sustainable channel to bridge development gaps.

The rest of the article proceeds as follows. Section 2 briefly reviews the literature on inequality and entrepreneurship. Section 3 describes the datasets used and methodology used. Section 4 presents the baseline results, whilst Section 5 offers robustness checks. The last section concludes.

\section{Impact of inequality on entrepreneurship}

The impact that inequality might have on development has been greatly debated in the literature. In this section, we briefly discuss some of the most prominent views, focusing on the alleged role that inequality might have for entrepreneurial activity in the long-run.

\subsection{Does inequality deter entrepreneurial activity?}

One view within the theoretical literature is that initial conditions can have long-term consequences for development, particularly if starting from high levels of wealth/income inequality. Inequality could affect development through different channels. For instance by leading to inefficient institutions (Glaeser et al., 2003), political instability (Alesina and Perotti, 1996, Bénabu, 1996), affecting the size, composition of domestic demand and level of industrialization (Jaramillo, 1995; Murphy et al., 1989) and preventing individuals from taking up profitable investments in capital (Evans and Jovanovic, 1989; Banerjee and Newman, 1993) or human capital (Galor and Zeira, 1993; Galor and Moav, 2004).

For instance, high levels of inequality could lead to political pressure to set up inefficient levels of taxation thereby hindering growth (Perotti, 1996; Persson and Tabellini, 1994). This could be as in Alesina and Rodrick (1994) who argue high levels of inequality could lead to the majority of people voting for high capital taxes. These high taxes reduce the 
incentives to accumulate capital thereby reducing growth. The damaging effect of inequality on growth could also be reached if wealthier individuals lobby against policies that seek to redistribute wealth and foster a more inclusive growth path (Bénabu, 1996).

Other scholars have argued that early wealth distribution determines whether a country industrializes by affecting market size (Murphy et al., 1989), the adoption of modern production technologies, productivity, and the number of workers employed in the modern sector (Jaramillo, 1995). Similarly, others argue that differences in wealth, particularly under the presence of imperfect credit markets, can be detrimental to growth. For instance, Banerjee and Newman (1993) assume in an overlapping generations model that each agent can choose to become a wage-earner or an entrepreneur which requires a larger up-front investment than the one required to become a self-employed. These up-front investments can be financed from would-be entrepreneurs' own wealth or by requesting a loan. However, due to the possibility that people could renege on their debts, lenders will be willing to loan only to those that can put in place collateral. Thus, people who do not have enough wealth to provide such collateral will be credit-constrained and be destined to be workers or unemployed. More importantly, the initial distribution of wealth in this model, in particular, the ratio of credit to non-credit constrained, determines who can invest, occupational returns, bequests and endowments across generations. Countries with low inequality -in the sense of having a high proportion of non-credit constrained people- will grow over time by having a large share of the population being able to establish businesses that survive over time paying high salaries. A contrasting equilibrium, however, could be reached if a country starts with high levels of inequality in the sense of having a small proportion of non-credit constrained people and very large proportion of credit constrained people. In this case, in the long-run, there will be a very large number of poor wage-earners and a small number of entrepreneurs. 
In terms of empirical evidence, the extensive literature review of Bénabu (1996) shows that although most studies find a negative association between inequality and economic growth, still there is no consensus. A more recent review by De Dominicis et al. (2006) coincides that older studies using data for the mid-1990s and before show a negative relationship between inequality and growth. Nonetheless, most recent empirical studies have tended to find a positive relationship instead. Voitchovsky (2009) reports in another literature review that despite several studies finding high inequality associated with lower growth rate, still no consensus has been reached. She argues that the mixed results might obey as high inequality at the bottom of the distribution hinders growth, but high inequality at the top is associated with higher growth rate.

With regards to the effect on entrepreneurship, Quadrini (1999) using the Panel Study of Income Dynamics in the USA for the 1980s finds that only those with sufficient personal wealth can start up a business since relying on external funds alone is insufficient. Similarly, Evans and Jovanovic (1989) in a study from the National Longitudinal Survey of Young Men in the USA find evidence that would-be entrepreneurs must bear most of the risk from their ventures. As a result, wealthier people are most likely to become entrepreneurs, evidence that agrees with other recent studies (Fairlie and Krashinsky, 2012). Although some find that liquidity constraints deter self-employment for poorer households (Gentry and Hubbard, 2004; Zissimopolos et al., 2009), others find no evidence of a necessary binding liquidity constraint (Hurst and Lusardi, 2004). As Frid et al. (2016) argue, this mixed evidence might be explained by two factors. First, the empirical literature has typically not considered the initial wealth of the household, prior to becoming an entrepreneur. Second, empirical studies often focus on only people that have businesses already established, omitting assessing start-ups. To overcome these limitations, Fried et al. (2016) use the Panel Study of Entrepreneurial Dynamics II from 1214 nascent entrepreneurs in the USA. They find that initial wealth of the 
entrepreneur, does not constrain start-ups, but it is an important determinant of entrepreneurial success. In similar fashion, Holtz-Eakin et al. (1994), using data from individual income tax returns of people who received inheritances, find that liquidity constraints are an important deterrent to engaging in entrepreneurial activities and for entrepreneurs to survive and grow in the medium to long-run.

Evidence from developing countries suggests that despite start-up costs for small businesses being significantly low, there is still evidence to support liquidity constraints. For instance, Mesnard and Ravallion (2001) find the number of business start-ups in Tunisia is an increasing function of aggregate wealth, where higher the wealth inequalities produce lower overall rates of new business start-ups. The evidence on this later point is nonetheless inconclusive. For instance, other studies have found a positive association between moderate levels of inequality and entrepreneurship, thus suggesting that inequality might also encourage business participation, particularly in developing countries (Rapoport, 2002; Naudé, 2008).

\subsection{Does inequality foster entrepreneurial activity?}

Other studies have instead argued for the positive role that inequality might have on entrepreneurial activity. Within this view, references to self-made millionaires and offspring of working class or migrants that became successful business owners are put as clear examples that lacking access to financial markets or having limited wealth are not necessarily a binding constraint. The critics of the importance of liquidity constraints for nascent entrepreneurship are not oblivious that the survival of business might depend not only on the ability of the entrepreneur but also on access to financial resources to survive (Aldrich and Fiol, 1994). Nonetheless, sociologists such as Aldrich (1999) suggest that economic models tend to put too much emphasis on the importance that income might play for nascent entrepreneurship. Besides, even within the economic literature, there are scholars that suggest wide differences 
in returns to capital or education might actually provide incentives for people to work harder to try to take up profitable investments (Rosenzweig and Binswanger, 1993). If people are able to take these investments, then these cases could represent important source mobility for current and future generations (Keister, 2000; Lippmann et al., 2005). Thus, past inequality might not necessarily be a deterrent for entrepreneurial activity nor a determinant for future inequality.

For instance, Lippman et al. (2005) using the Global Entrepreneurship Monitor (GEM), the same survey used in this article, find that inequality has a positive effect on overall entrepreneurial activity. These authors argue that this positive finding is perhaps given that those in the top of the distribution have enough financial resources to set up their business and those at the bottom some might become self-employed rather than earning low wages. Similarly, Lecuna (2014) finds that the Gini coefficient has a positive effect on the Total EarlyStage Entrepreneurial Activity (TEA) as measured by the GEM survey using data from 54 countries over 2005-2009. This result is robust if the entry density is derived from the World Bank Group Entrepreneurship Snapshot.

Given the ambiguous impact that inequality and wealth constraints might have on entrepreneurship, some empirical studies have distinguished those businesses that were opened out of need, and those seeking an opportunity in the market (Reynolds et al., 2005). For instance, Lippmann et al. (2005) use the GEM survey to find that inequality has a positive association with the entrepreneurial activity initiated out of need. Similarly, inequality is positively associated with the total entrepreneurial activity that is initiated to seize a business opportunity; however, this positive relationship was found up to a point, only for countries with a Gini coefficient of 45 or less. Beyond that level, this relationship becomes negative, which was the case for Latin American countries such as Mexico, Chile and Brazil. In these cases, 
the high levels of inequality are negatively associated with the entrepreneurial activity that was initiated to seize market opportunities.

In line with the discussed literature, this article seeks to test the following two hypotheses.

Hypothesis 1: Historical levels of inequality are negatively associated with the net entrepreneurial activity (in terms of start-up and the established firms) over time.

Hypothesis 2: Historical levels of inequality are positively associated with higher levels of entrepreneurial activity for start-ups opened out of need. Since these start-ups are unlikely to survive, inequality is likely to have null effects on those established firms that were originally opened out of need.

To prevent the likely endogenous relationship between inequality and entrepreneurial activity, unlike much of similar previous empirical literature, we use historical estimators of income inequality for the distant past, dating back to early 1800s. This approach also allows us to more directly test the predictions of the theoretical literature that argues initial conditions influence the accumulation of wealth across generations, thereby affecting entrepreneurship activity over time. Moreover, to assess whether the impact of inequality remains strong over time, we also use other inequality indicators across different points in time.

\section{Data and Methodology}

\subsection{Historical Statistics}

The theoretical literature has highlighted that credit market imperfections exacerbate the detrimental impact that inequality may have on investments and output over time (Aghion et al., 1999; Banerjee and Newman, 1993; Galor and Zeira, 1993). It is argued that if a large percentage of the population is credit-constrained, they and their offspring, in turn, will be unable to take up potentially profitable activities, thus, reducing the number of start ups and 
investment in human capital. As a result, a country with such conditions will remain with low returns over time. To test these theoretical implications ideally we would need historical statistics on the percentage of people that might have been credit and non-credit constrained. Since there are no such historical statistics, we instead use the readily available historical estimators of income distribution across the globe dating back to early 1800s. Our implicit assumption is that these historical inequality measures are a good proxy for the historical ratio of people that were credit and non-credit constrained in the distant past. This assumption is based on contemporaneous evidence that suggests poorer people are often credit-constrained. That is the case as poor population lack enough wealth to provide collateral or live far from a banking institution, thus affecting their chances of obtaining credit (Baliamoune-Lutz et al., 2011; Berg, 2013). Later on, in Section 5, as a robustness check, we show evidence that these historical inequality measures correlate well with current measures of credit availability for the wealthy and poor income groups.

Specifically, we use Bourguignon and Morrisson (2002) estimates of the world income distribution spanning from the 19th century until the 20th century. These authors were the first to provide a broad historical picture about the levels of global inequality. This study provides income share by decile, which we use to build different inequality indicators ranging from the traditional Gini coefficient to different ratios of income shares across deciles.

Bourguignon and Morrisson (2002) estimated the historical income distribution around the globe using several sources of historical GDP per capita and population. ${ }^{3}$ Since these

\footnotetext{
${ }^{3}$ To estimate the distribution of income three main variables were used: the real GDP expressed in constant purchasing power parity (PPP) dollars; population size, and the distribution of income summarised by nine decile income shares, and the top two vintile shares. The sources of these indicators include the historical estimates of GDP per capita and population from Maddison (1995 cited by Bourguignon and Morrisson 2002, p. 729), those of Berry et al. (1983a, b, cited by Bourguignon and
} 
historical indicators were not available for a few countries, these authors grouped a few countries to minimize problems of missing income distribution data. The groupings were based on considerations of economic and historical consistency. In total, the authors estimated the income distribution for 33 countries or groups of countries. Those countries whose weight in the world is significant were considered individually, that is the case of China, India, Italy and the USA to mention a few. Others such as Sub-Saharan and Latin America were broken down into sub-groups according to their economic evolution and homogeneity. In Table A.1, in the Appendix, we include the list of individual countries and sub-groups and for which we have such estimators of income inequality.

Given the use of historical data these income inequality indicators should be taken as suggestive of the levels and dynamics of historical income distribution and not necessarily at face value. Particularly, those related to the far distant past. For this reason, we also use the indicators by Bourguignon and Morrisson (2002) for a more recent period, including 1980s. These recent indicators provide a more reliable picture of the recent inequality levels.

Table 1 provides the descriptive statistics for the three measures of inequality we use across 66 countries at three points in time 1820, 1910 and 1980. Given the relative stability of inequality over time, we focus on estimating our regressions in the next section only using these years as inequality around other nearby years reaches same results as those presented.

On average, inequality increased slightly from 1820 to 1910 . That was the case if using the traditional Gini coefficient or the two other measures of inequality we constructed. That is

Morrisson 2002, p. 730) for the pre- and post-World War II period. More recent data for historical data, the USA and UK, for instance, were drawn from Lindert (2000 cited by Bourguignon and Morrisson 2002, p. 730) and for continental Europe from Morrisson (2000 cited by Bourguignon and Morrisson 2002, p. 730). To fill in the gaps in information, the authors in some cases also used growth rates observed for comparable neighbouring countries over the same period. 
the ratio of income share of the top $9^{\text {th }}$ decile to bottom decile, and the ratio of the income share of the top four deciles to that of the bottom four deciles. Moreover, inequality on average fell comparing 1980 to the levels of both 1820 and 1910.

Table 1. Summary statistics on historical inequality

\begin{tabular}{lccccc}
\hline & Obs & Mean & Std. Dev. & Min & Max \\
\hline Inequality measures & & & & & \\
Gini 1820 & 66 & 0.47 & 0.05 & 0.34 & 0.62 \\
Gini 1910 & 66 & 0.49 & 0.04 & 0.34 & 0.62 \\
Gini 1980 & 67 & 0.42 & 0.09 & 0.28 & 0.59 \\
& & & & & \\
Ln ratio 9 to 1 income share for year 1820 & 66 & 1.97 & 0.29 & 1.22 & 2.48 \\
Ln ratio 9 to 1 income share for year 1910 & 66 & 2.01 & 0.27 & 1.22 & 2.48 \\
Ln ratio 9 to 1 income share for year 1980 & 66 & 1.84 & 0.28 & 1.11 & 2.39 \\
& & & & & \\
In ratio top 4 deciles to bottom 4 deciles year 1820 & 66 & 1.72 & 0.26 & 1.15 & 2.48 \\
In ratio top 4 deciles to bottom 4 deciles year 1910 & 66 & 1.77 & 0.23 & 1.15 & 2.48 \\
In ratio top 4 deciles to bottom 4 deciles year 1980 & 66 & 1.53 & 0.35 & 0.93 & 2.33
\end{tabular}

Despite the decline of inequality in the 20th century, countries that started from being highly unequal in 1820 remained so over time, and the ones that started more egalitarian also remained so over time. That is the case if measuring inequality with the Gini coefficient, as shown in Figure 1, Panel A, and with any other ratio of income share deciles. Figure 1, Panel $\mathrm{B}$, for instance, shows the strong linear relationship between the ratio of the income share of 9 decile to the bottom decile in 1820 and 1980. 


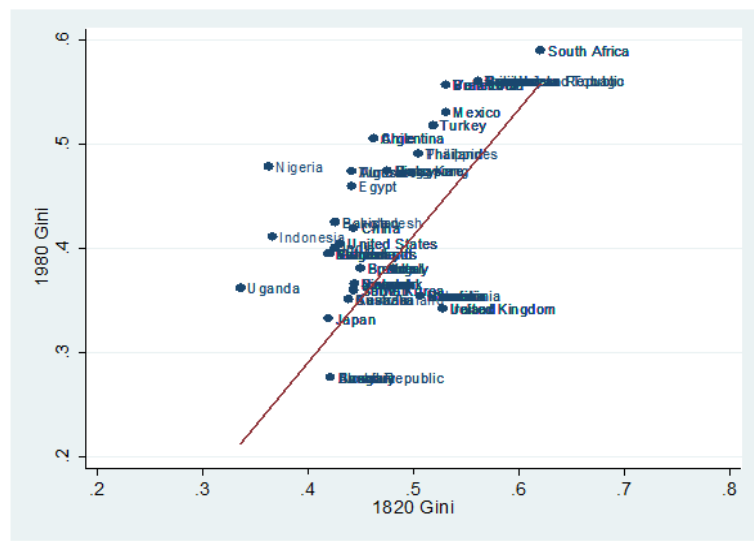

Panel A

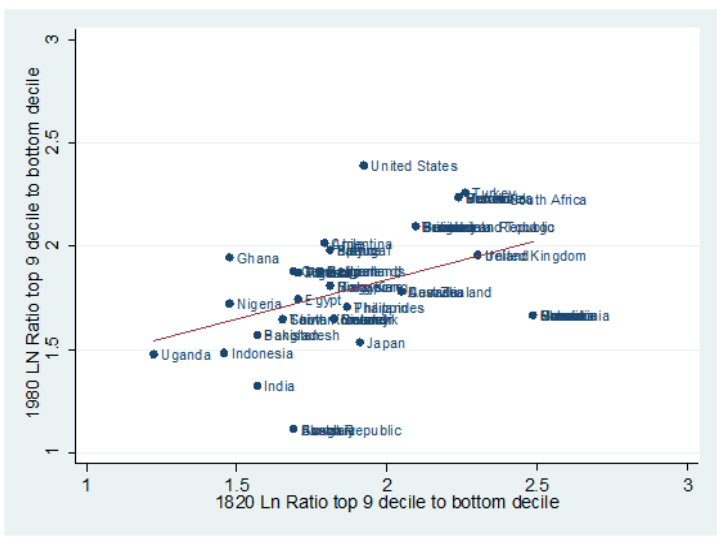

Panel B

Figure 1. Inequality for years 1820 and 1980

\subsection{GEM Survey}

To assess the extent of entrepreneurial activity, ranging from creation to maturity of businesses, we use the Global Entrepreneurship Monitor (GEM) survey. The GEM survey is the largest study of entrepreneurial activity around the globe, which draws nationally representative samples on an annual basis across more than 80 countries.

To study the dynamics of entrepreneurship, we consider the Early-Stage Entrepreneurial Rate (TEA) as defined by GEM. That is the percentage of the adult population in the process of setting up a business they will own or co-own, or that currently own, manage and operate a young business that is up to 3.5 years old (Reynolds et al., 2005). We also consider the percentage of the adult population that have established firms, understood as those who own, manage a firm and that have paid salaries or wages to the owners or workers for more than 3.5 years. These two indicators reveal not only the number of firms that are created in each country, but also importantly how many of these survive over time.

For our analysis, we focus on the 66 countries surveyed in GEM that were at least surveyed in one year during the period 2005-2011 and for which we have also historic information on income distribution. The countries analysed are listed in Table A.2, whereas 
Table A.3 provides a description of the variables used and data sources. ${ }^{4}$ In our period of analysis, on average $9.6 \%$ owned a young firm, and $7.6 \%$ had an established firm as shown in Table 2. Crucial for our study is to test whether these contemporaneous indicators of entrepreneurial activity are associated with the levels of income inequality prevailing in the distant past.

Table 2. Summary statistics

\begin{tabular}{|c|c|c|c|c|c|c|c|c|}
\hline & Average & & & & & & & \\
\hline & $2005-2011$ & 2005 & 2006 & 2007 & 2008 & 2009 & 2010 & 2011 \\
\hline \% Young firms (TEA) & 0.096 & 0.075 & 0.088 & 0.083 & 0.096 & 0.099 & 0.109 & 0.110 \\
\hline \%Established firms & 0.076 & 0.065 & 0.069 & 0.064 & 0.086 & 0.079 & 0.087 & 0.071 \\
\hline \%Personally knows someone who started a & & & & & & & & \\
\hline business 2 years ago & 0.417 & 0.419 & 0.424 & 0.435 & 0.440 & 0.445 & 0.417 & 0.350 \\
\hline Number of selected countries in GEM surveys & 66 & 33 & 39 & 36 & 44 & 41 & 48 & 50 \\
\hline Number of respondents in GEM surveys & 889,863 & 105,638 & 153,989 & 136,819 & 113,715 & 130,259 & 127,973 & 121,470 \\
\hline Access to credit (\%GDP) & 108.1 & 134.4 & 115.1 & 115.9 & 106.2 & 100.2 & 100.6 & 96.3 \\
\hline Number of procedures starting a business & 7.556 & 6.333 & 7.000 & 7.324 & 7.639 & 8.340 & 8.060 & 7.522 \\
\hline Political stability & 0.186 & 0.547 & 0.246 & 0.268 & 0.112 & -0.006 & 0.108 & 0.183 \\
\hline Control of corruption & 0.532 & 1.115 & 0.803 & 0.758 & 0.134 & 0.309 & 0.413 & 0.491 \\
\hline GNI per capita in 2000 & 17509.6 & 21789.7 & 19614.2 & 19818.8 & 15659.5 & 16123.6 & 14977.3 & 16773.5 \\
\hline
\end{tabular}

Figure 2, Panel A, illustrates the negative association found between the average percentage of the population that was engaged in early entrepreneurial activity (TEA) during 2005-2011 and the 1820 ratio of the income share of the 9th decile to the bottom decile, one of our indicators of inequality. This negative relationship is also evident in Panel B. That plot depicts the relationship between the inequality ratio for 1820 and the percentage of the adult population that own and manage an established firm during 2005-2011.

\footnotetext{
${ }^{4}$ In total, 1,526,407 people across 89 countries were interviewed by GEM over 2005-2011. From these, we discard the responses from 23 sampled countries as we have no historical statistics on inequality for these cases. Thus we remain with 889,863 respondents across 66 countries.
} 
Figure 2 suggests that countries that in the distant past had a higher level of income gap between the wealthy and poor over time developed a lower rate of entrepreneurial activity. This simple linear relationship, however, excludes various other factors that affect entrepreneurial activity. Thus, our econometric assessment presented in the following sections also control for other indicators, apart from inequality.
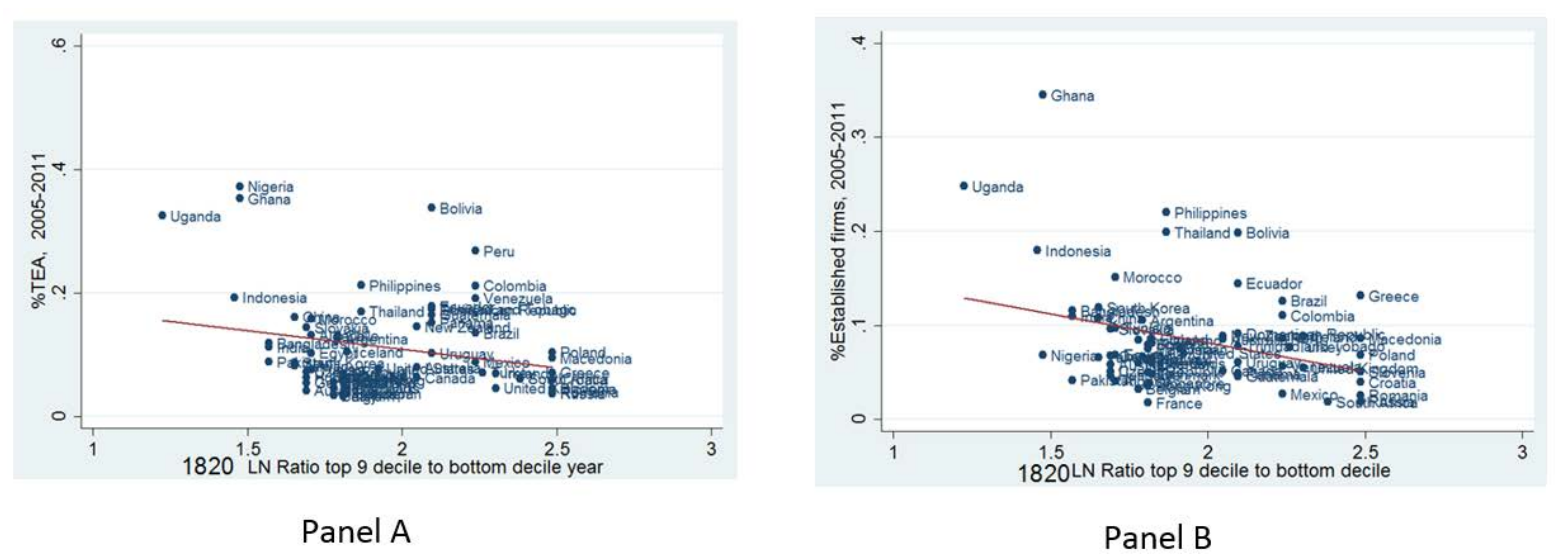

Figure 2. Percentage of total early-state entrepreneurial activity (TEA) and established firms over 2005-2011 and the ratio of the income share top 9 decile to the bottom decile for year 1820

Following the literature on entrepreneurship, we also consider the percentage of the adult population who personally know someone who started a new business during the last two years, data drawn from the GEM survey. The presence of 'entrepreneurial roles' has been found in previous studies to strongly influence the creation of firms (Ardanga and Lusardi, 2008). We also add education as it has been identified as an important factor in accessing information and identifying business opportunities that might aid in the creation and management of firms (Naudé, 2010; Ordeñana and Arteaga, 2012). Our indicator is specifically the percentage of the adult population that has post-secondary education or higher level, which is drawn from nationally representative GEM surveys. 


\subsection{Current institutional and business environment}

We also control for the impact that current credit market and institutions might have on entrepreneurial activity, adding four other indicators. To measure the availability of credit, we use the domestic credit provided by the banking sector from the World Bank, which includes all credit to the various sectors, as the percentage of the Gross Domestic Product (GDP), from 2005 until 2011. To proxy for other institutional costs that might impede the creation of firms, we control for the number of procedures that are officially required for an entrepreneur to start up and formally operate a business based on data from the World Bank’s Doing Business from 2005 until 2011. We also consider other institutional aspects that might deter the creation and maturity of firms. These are as follows: political stability and control of corruption, both obtained from the Worldwide Governance Indicators (WGI) projects from 2005 until 2011 (Kaufmann et al., 2010). These two variables range from -2.5 to 2.5, with the higher the score denoting better institutions. ${ }^{5}$

Finally, we also use the Gross National Income (GNI) at purchasing power parity. We use this statistic to take into account the current level of economic development, a key factor found in previous literature to explain the level of entrepreneurial activity (Alvarez and Urbano 2011; Wennekers et al., 2005). To avoid a potential endogenous relationship between the GNI per capita and the number of firms, we use the value of GNI of the year 2000 exclusively.

Table 2 reports the descriptive statistics for our key aggregate indicators for the whole sample on average for 2005-2011 and for each of these years.

\footnotetext{
${ }^{5}$ Political stability measures the probability that the government will be destabilised or overthrown by unconstitutional or violent means, including politically-motivated violence and terrorism. Control of corruption measures the perceptions of the extent to which public power is exercised for private gain, as well as the capture of the state by elites and private interests.
} 


\subsection{Panel random effects}

We use panel random effects to measure the extent to which historical measures of inequality, our proxy for past access to credit, affects entrepreneurial activities over time using the GEM survey. Since GEM draws new nationally representative samples each year, the surveys remain representative of the population engaged in entrepreneurial activities over time, avoiding an attrition bias commonly found in firm's surveys. Equation (1) denotes the panel random effects regression we estimate.

$$
y_{i t}=\alpha+\beta_{1} \text { Historical inequality }+\beta_{2} x_{i t}+\beta_{3} X_{i}+\beta_{4} \text { Region }_{i}+\beta_{5} \text { Year }_{t}+\varepsilon_{i t}
$$

where $y_{i t}$ denotes the percentage of the adult population engaged in entrepreneurial activity in country $i$ and time $t$. $x_{i t}$ represents the vector of our explanatory variables that change over time. $X$ are time invariant country’s covariates. Region is a set of dummy variables (for Africa, Asia, Europe, Latin America, North America, Oceania and the Middle East) to take into account time-invariant characteristics, such as geography or other time-invariant institutional factors. Year denotes year fixed effects that allow us to take into account changes in economic activity over the period analysed. $\varepsilon_{i t}$ refers to the random error. Our coefficient of interest $\beta_{1}$ tests whether the entrepreneurial activity over the period analysed, 2005-2011, depends on the level of inequality that countries had in the distant past. To interpret this coefficient as elasticity, we measure both entrepreneurial activity and the historical inequality indicators in natural logarithm.

We estimate all the panel regressions using country random effects given the versatility of this type of specification. Specifically, the random effects model allows us to test the impact of two types of covariates: for those for which we do not have yearly data (such as our historical measure of inequality) and those time variant (as many of our institutional controls that vary on a yearly basis). The random effects model is commonly used whenever having time- 
invariant explanatory variables (e.g. our historical measure of inequality) that are of great theoretical importance to test as the effects of this type of variables are impossible to measure in panel fixed effects model (Mehmetoglu and Jakobsen 2017, p. 251). The random effects model yields unbiased and efficient estimates provided that there is no (or little) covariance between the error term and the explanatory variables, as we show that is our case in section 5 . Moreover, the Hausman's specification tests suggest we should adopt the random specification as yields consistent and more efficient estimates than the fixed effects specification. ${ }^{6}$

\section{Econometric Results}

\subsection{To what extent historical inequality affects contemporaneous entrepreneurial activity?}

Table 3 reports the panel random country effects regression of the log of entrepreneurial activity on historical inequality using robust standard errors across all models. Columns (1) to (4) focus on the log of the percentage of people engaged in early entrepreneurial activity (TEA). Columns (5) to (8) instead focus on the log of the percentage of people engaged in established business. As a measure of historical inequality, we use the log of the ratio of the income share of the top $9^{\text {th }}$ decile and the bottom decile. We separately test the effects of this indicator if measured for the year 1820, 1910 and 1980.

\footnotetext{
${ }^{6}$ We have unbalanced panel regression given that the countries analysed do not appear across every single year analysed. The Hausman test when using the log of TEA as our dependent variable is equal to $\chi^{2}=10.18$ with a probability> $\chi^{2}=0.6002$, which accepts the null hypothesis that states the random effects and fixed effects are both consistent, but fixed effects is inefficient; thus the random specification should be preferred. Similarly, the Hausman test when using the log of the percentage of the population that have an established business as our dependent variable is equal to $\chi^{2}=11.39$ with a probability> $\chi^{2}=0.4958$.
} 
Confirming our first hypothesis, all models estimated show there is a strong and statistically significant negative correlation between the measures of historical inequality and entrepreneurial activity conducted over 2005-2011. That is, the larger the income share held by the wealthy relative to the poor the lower the share of people involved in young or established firms. For instance, a 1\% increase in the historic ratio of wealthy to poor reduces the proportion of people involved in young firms by around $4 \%$ and the proportion of people involved in established firms by $6 \%$ in established firms. These effects are quite similar for the historical measures of inequality of 1820, 1910 and 1980, albeit higher for more recent indicators, suggesting that the detrimental impact of inequality increases over time. These results are also consistent if controlling for current credit and institutional factors or not, as seen in columns (1) and (5). Interestingly, the level of entrepreneurial activity is not significantly affected by the contemporaneous access to credit or by the level of GNI per capita in 2000. We also explored whether the absolute level of GNI in the distant past (in 1820) affected current entrepreneurial activity, finding no effect thus the results are not shown in the table. These findings suggest that current entrepreneurial activity is more strongly dependent of past income distribution (our proxy for how credit was distributed among the poor and rich) than our measures of contemporaneous levels of credit or GNI.

Table 3. Entrepreneurial activity during 2005-2011 and historical inequality, panel random effects 


\begin{tabular}{|c|c|c|c|c|c|c|c|c|}
\hline & $\begin{array}{c}\text { (1) } \\
\text { Lntea }\end{array}$ & $\begin{array}{c}\text { (2) } \\
\text { Lntea }\end{array}$ & $\begin{array}{c}\text { (3) } \\
\text { Lntea }\end{array}$ & $\begin{array}{c}\text { (4) } \\
\text { Lntea }\end{array}$ & $\begin{array}{c}\text { (5) } \\
\text { Lnestablished }\end{array}$ & $\begin{array}{c}\text { (6) } \\
\text { Lnestablished }\end{array}$ & $\begin{array}{c}(7) \\
\text { Lnestablished }\end{array}$ & $\begin{array}{c}\text { (8) } \\
\text { Lnestablished }\end{array}$ \\
\hline Ln ratio 9 to 1 income share for year 1820 & $\begin{array}{c}-0.322^{* *} \\
(0.162)\end{array}$ & $\begin{array}{c}-0.391 * * \\
(0.161)\end{array}$ & & & $\begin{array}{c}-0.583 * \\
(0.323)\end{array}$ & $\begin{array}{c}-0.687 * \\
(0.357)\end{array}$ & & \\
\hline Ln ratio 9 to 1 income share for year 1910 & & & $\begin{array}{c}-0.419 * * \\
(0.172)\end{array}$ & & & & $\begin{array}{c}-0.739 * \\
(0.396)\end{array}$ & \\
\hline Ln ratio 9 to 1 income share for year 1980 & & & & $\begin{array}{c}-0.478 * * \\
(0.225)\end{array}$ & & & & $\begin{array}{c}-0.674 * \\
(0.344)\end{array}$ \\
\hline Political stability & & $\begin{array}{l}-0.160 * \\
(0.089)\end{array}$ & $\begin{array}{l}-0.159 * \\
(0.090)\end{array}$ & $\begin{array}{c}-0.215^{* * *} \\
(0.082)\end{array}$ & & $\begin{array}{l}-0.061 \\
(0.112)\end{array}$ & $\begin{array}{l}-0.060 \\
(0.113)\end{array}$ & $\begin{array}{l}-0.122 \\
(0.113)\end{array}$ \\
\hline Control corruption & & $\begin{array}{c}0.040 \\
(0.084)\end{array}$ & $\begin{array}{c}0.044 \\
(0.085)\end{array}$ & $\begin{array}{c}0.024 \\
(0.071)\end{array}$ & & $\begin{array}{c}-0.034 \\
(0.137)\end{array}$ & $\begin{array}{l}-0.029 \\
(0.138)\end{array}$ & $\begin{array}{l}-0.047 \\
(0.130)\end{array}$ \\
\hline Number procedure start business & & $\begin{array}{c}0.009 \\
(0.012)\end{array}$ & $\begin{array}{c}0.008 \\
(0.012)\end{array}$ & $\begin{array}{c}0.010 \\
(0.012)\end{array}$ & & $\begin{array}{c}0.018 \\
(0.018)\end{array}$ & $\begin{array}{c}0.017 \\
(0.019)\end{array}$ & $\begin{array}{c}0.019 \\
(0.017)\end{array}$ \\
\hline Access to credit & & $\begin{array}{c}0.000 \\
(0.001)\end{array}$ & $\begin{array}{c}0.000 \\
(0.001)\end{array}$ & $\begin{array}{c}0.001 \\
(0.001)\end{array}$ & & $\begin{array}{c}0.001 \\
(0.001)\end{array}$ & $\begin{array}{c}0.001 \\
(0.001)\end{array}$ & $\begin{array}{c}0.002 * * \\
(0.001)\end{array}$ \\
\hline GNI per capita 2000 & $\begin{array}{c}-0.000 * * * \\
(0.000)\end{array}$ & $\begin{array}{c}-0.000 * * \\
(0.000)\end{array}$ & $\begin{array}{c}-0.000 * \\
(0.000)\end{array}$ & $\begin{array}{l}-0.000 \\
(0.000)\end{array}$ & $\begin{array}{l}-0.000 \\
(0.000)\end{array}$ & $\begin{array}{l}-0.000 \\
(0.000)\end{array}$ & $\begin{array}{l}-0.000 \\
(0.000)\end{array}$ & $\begin{array}{l}-0.000 \\
(0.000)\end{array}$ \\
\hline \%Personally knows someone who started & & & & & & & & \\
\hline a business 2 years ago & $\begin{array}{c}1.605^{* * *} \\
(0.253)\end{array}$ & $\begin{array}{c}1.518^{* * *} \\
(0.304)\end{array}$ & $\begin{array}{c}1.532^{* * *} \\
(0.303)\end{array}$ & $\begin{array}{c}1.520 * * * \\
(0.305)\end{array}$ & $\begin{array}{c}0.479 \\
(0.329)\end{array}$ & $\begin{array}{c}0.822 * * \\
(0.393)\end{array}$ & $\begin{array}{c}0.839 * * \\
(0.390)\end{array}$ & $\begin{array}{c}0.829 * * \\
(0.412)\end{array}$ \\
\hline$\%$ Post-secondary education & $\begin{array}{c}0.165 \\
(0.200)\end{array}$ & $\begin{array}{c}0.521^{* *} \\
(0.239)\end{array}$ & $\begin{array}{c}0.506 * * \\
(0.238)\end{array}$ & $\begin{array}{c}0.527^{* *} \\
(0.236)\end{array}$ & $\begin{array}{c}-0.022 \\
(0.215)\end{array}$ & $\begin{array}{c}0.187 \\
(0.266)\end{array}$ & $\begin{array}{c}0.169 \\
(0.264)\end{array}$ & $\begin{array}{c}0.195 \\
(0.256)\end{array}$ \\
\hline Region fixed effects & Yes & Yes & Yes & Yes & Yes & Yes & Yes & Yes \\
\hline Year fixed effects & Yes & Yes & Yes & Yes & Yes & Yes & Yes & Yes \\
\hline Observations & 270 & 217 & 217 & 216 & 270 & 217 & 217 & 216 \\
\hline Number of countries & 64 & 52 & 52 & 51 & 64 & 52 & 52 & 51 \\
\hline
\end{tabular}

Notes: Robust standard errors in parentheses. Significance levels $* * * p<0.01, * * p<0.05, * p<0.1$

To assess the robustness of these findings, we also consider different measures of historical inequality. For instance, Table A.4 shows the log of the ratio of the income share of the top four deciles to the bottom four deciles, and the traditional Gini coefficient. ${ }^{7}$ For these two measures of inequality, we also find a strong and statistically significant negative correlation with entrepreneurial activity.

The consistency of the findings with alternative inequality measures across different historical points is reassuring. Particularly so given that it is unclear what specific period should be taken as a relevant starting point to assess the historical impact of inequality over time. For instance, one could argue that the income distribution in the year 1820 might be more relevant for Latin America, as back then colonising institutions had been implemented, resulting in high

\footnotetext{
${ }^{7}$ We present these only for the year 1820 only as the results for year 1910 and 1980 also remain similar in statistical significance and sign.
} 
levels of inequality. ${ }^{8}$ Similarly, 1820 might also be quite relevant for Europe as this period witnessed the transition to new manufacturing processes that lead to the industrial revolution. Thus, the income distribution back then provided crucial to decide how many people could set up businesses or become wage-earners. Although one could argue that perhaps the most relevant starting point for Africa is closer to 1920 given that by then much of the continent had been colonised by European powers, one should also consider that pre-colonial institutions have been linked to the slow development of the region (Michalopoulos and Papaioannou, 2011). Regardless of what initial point might be regarded as more relevant for Africa, the inequality distribution for the continent had very little changes from 1820 to 1910, and afterward. The lack of significant changes might well be because many pre-colonial local elites were used by colonisers to implement their rule, preserving their preferential status. The small tax-redistributive nature of independent African governments also explain the low investment in public goods in the region (Acemoglu and Robinso, 2010).

With regard to the controls used, we find that political stability also has a strong and negative association with entrepreneurial activity, but only for young firms, as shown in Table 3. There is not much evidence that our measures of the number of procedures required to start a business, control of corruption or domestic credit affect the creation of firms. In general, the findings of political stability and lack of effect on our measure of credit markets coincides with those of Alvarez and Urbano (2011) who also used these indicators to explore the association between these variables and entrepreneurial activities for young firms using the GEM survey.

We also find education has a positive effect for early-stage entrepreneurial activity, but no effect on established firms. This mixed evidence has also been found in other studies. For

\footnotetext{
${ }^{8}$ Engerman and Sokoloff (2005) stress that the colonial institutions in the region perpetuated unequal opportunities given the low taxes for the wealthy and low public investment in education, and infrastructure conducive to (inclusive) growth.
} 
instance, those that find a positive correlation between education and entrepreneurial activity argue that education helps people identify business opportunities, and as such, higher education levels produce higher engagement in new business opportunities (Simón-Moya et al., 2014). However, for running established business entrepreneurial-specific knowledge and previous business experience is more relevant than simply having higher a level of education attainment (Man et al., 2002).

The estimated coefficient of knowing someone who started a business two years ago is positive and statistically significant. This finding is consistent with the existing literature on entrepreneurial role models (Krueger, 1993; Shapero and Sokol, 1982). We also find a negative (albeit quite weak) and statistically significant relationship between the GNI per capita for 2000, which we use as a baseline for development level, and entrepreneurial activity, particularly in young firms. This negative association has also been found in previous studies (Alvarez and Urbano 2011; Reynolds et al., 2001). ${ }^{9}$ A potential explanation for this finding is that as countries develop, the percentage of people who needs to open a business out of need decreases.

\subsection{Does historical inequality fosters out of need entrepreneurship?}

We re-run our analysis to test our second hypothesis. However, this time we focus only on the percentage of people who stated in GEM survey opened their business out of need as 'there were no better choices for work'. Roughly a third of entrepreneurs engaged in young firms and in established firms stated that out of need was the reason they engaged in their current business. As expected, Table 4 shows a positive and statistically significant relationship

\footnotetext{
${ }^{9}$ We also find this weak negative relationship if using instead the absolute level of GNI in the distant past (in 1820). These results are not presented as the regression coefficients are nearly equal to zero.
} 
between our historical measure of inequality and the percentage of people involved in these young firms. That is, as expected, the higher income shares of the wealthy relative to the poor produce higher shares of people that will open firms out of need. There is however mixed evidence about this relationship for established firms (firms that have survived for longer than 3.5 years). As column (4) shows, this relationship with inequality is positive, but are no longer statistically significant in columns (5) and (6). These findings suggest that although more unequal countries have a higher probability of people opening firms out of need, these might not survive in the short and medium-run; thus, our lack of association between inequality and established firms opened out of need. Overall, these findings are consistent with the high entrepreneurial activity of young firms noted in highly unequal developing countries, where although quite a few firms are opened each year, not many of them survive (Naudé, 2010).

Table 4. Firms opened for need during 2005-2011 and historical inequality, panel random effects 


\begin{tabular}{|c|c|c|c|c|c|c|}
\hline & $\begin{array}{c}(1) \\
\text { Lntea }\end{array}$ & $\begin{array}{c}(2) \\
\text { Lntea }\end{array}$ & $\begin{array}{c}(3) \\
\text { Lntea }\end{array}$ & $\begin{array}{c}\text { (4) } \\
\text { Lnestablished }\end{array}$ & $\begin{array}{c}\text { (5) } \\
\text { Lnestablished }\end{array}$ & $\begin{array}{c}\text { (6) } \\
\text { Lnestablished }\end{array}$ \\
\hline Ln ratio 9 to 1 income share for year 1820 & $\begin{array}{c}0.574 * * \\
(0.229)\end{array}$ & & & $\begin{array}{l}0.163^{*} \\
(0.095)\end{array}$ & & \\
\hline Ln ratio 9 to 1 income share for year 1910 & & $\begin{array}{l}0.437^{*} \\
(0.248)\end{array}$ & & & $\begin{array}{l}0.116 \\
(0.088)\end{array}$ & \\
\hline Ln ratio 9 to 1 income share for year 1980 & & & $\begin{array}{c}0.484 * * \\
(0.244)\end{array}$ & & & $\begin{array}{l}-0.024 \\
(0.151)\end{array}$ \\
\hline Political stability & $\begin{array}{l}-0.012 \\
(0.098)\end{array}$ & $\begin{array}{l}-0.016 \\
(0.098)\end{array}$ & $\begin{array}{c}0.020 \\
(0.104)\end{array}$ & $\begin{array}{c}0.041 \\
(0.055)\end{array}$ & $\begin{array}{c}0.039 \\
(0.055)\end{array}$ & $\begin{array}{c}0.029 \\
(0.058)\end{array}$ \\
\hline Control corruption & $\begin{array}{l}-0.172 \\
(0.132)\end{array}$ & $\begin{array}{l}-0.192 \\
(0.132)\end{array}$ & $\begin{array}{l}-0.203 \\
(0.131)\end{array}$ & $\begin{array}{l}-0.078 \\
(0.051)\end{array}$ & $\begin{array}{l}-0.085^{*} \\
(0.051)\end{array}$ & $\begin{array}{l}-0.099 * \\
(0.054)\end{array}$ \\
\hline Number procedure start business & $\begin{array}{l}-0.001 \\
(0.013)\end{array}$ & $\begin{array}{l}-0.002 \\
(0.013)\end{array}$ & $\begin{array}{l}-0.003 \\
(0.013)\end{array}$ & $\begin{array}{c}0.015^{* *} \\
(0.007)\end{array}$ & $\begin{array}{l}0.014^{*} \\
(0.007)\end{array}$ & $\begin{array}{c}0.012^{*} \\
(0.007)\end{array}$ \\
\hline Access to credit & $\begin{array}{l}-0.001 \\
(0.001)\end{array}$ & $\begin{array}{l}-0.001 \\
(0.001)\end{array}$ & $\begin{array}{l}-0.001^{*} \\
(0.001)\end{array}$ & $\begin{array}{c}0.000 \\
(0.001)\end{array}$ & $\begin{array}{c}0.000 \\
(0.001)\end{array}$ & $\begin{array}{c}0.000 \\
(0.001)\end{array}$ \\
\hline GNI per capita 2000 & $\begin{array}{l}-0.000 \\
(0.000)\end{array}$ & $\begin{array}{l}-0.000 \\
(0.000)\end{array}$ & $\begin{array}{l}-0.000 \\
(0.000)\end{array}$ & $\begin{array}{c}-0.000 * * * \\
(0.000)\end{array}$ & $\begin{array}{c}-0.000^{* * *} \\
(0.000)\end{array}$ & $\begin{array}{c}-0.000 * * * \\
(0.000)\end{array}$ \\
\hline $\begin{array}{l}\text { \%Personally knows someone who started } \\
\text { a business } 2 \text { years ago }\end{array}$ & 0.273 & 0.234 & 0.247 & -0.132 & -0.149 & -0.169 \\
\hline & $(0.556)$ & (0.564) & $(0.556)$ & $(0.296)$ & $(0.293)$ & $(0.304)$ \\
\hline$\%$ Post-secondary education & $\begin{array}{l}-0.517 \\
(0.337)\end{array}$ & $\begin{array}{l}-0.490 \\
(0.331)\end{array}$ & $\begin{array}{l}-0.488 \\
(0.325)\end{array}$ & $\begin{array}{c}0.042 \\
(0.206)\end{array}$ & $\begin{array}{c}0.053 \\
(0.208)\end{array}$ & $\begin{array}{c}0.057 \\
(0.208)\end{array}$ \\
\hline Region fixed effects & Yes & Yes & Yes & Yes & Yes & Yes \\
\hline Year fixed effects & Yes & Yes & Yes & Yes & Yes & Yes \\
\hline Observations & 217 & 217 & 216 & 217 & 217 & 216 \\
\hline Number of countries & 52 & 52 & 52 & 52 & 52 & 52 \\
\hline
\end{tabular}

Notes: Robust standard errors in parentheses. Significance levels ${ }^{* * *} p<0.01,{ }^{* *} p<0.05,{ }^{*} p<0.1$

\section{Robustness checks}

We conclude our analysis with three robustness checks to assess the validity and consistency of the results presented so far. First, in Table 5, we re-run the panel country random effects, but this time excluding Latin American countries, known for being the most unequal in the world historically. Once again, we find a strong and negative association between entrepreneurial activity and the ratio of wealthy to poor people for years 1820, 1910 and 1980 .

Table 5. Entrepreneurial activity during 2005-2011 and historical inequality excluding Latin America, panel random effects 


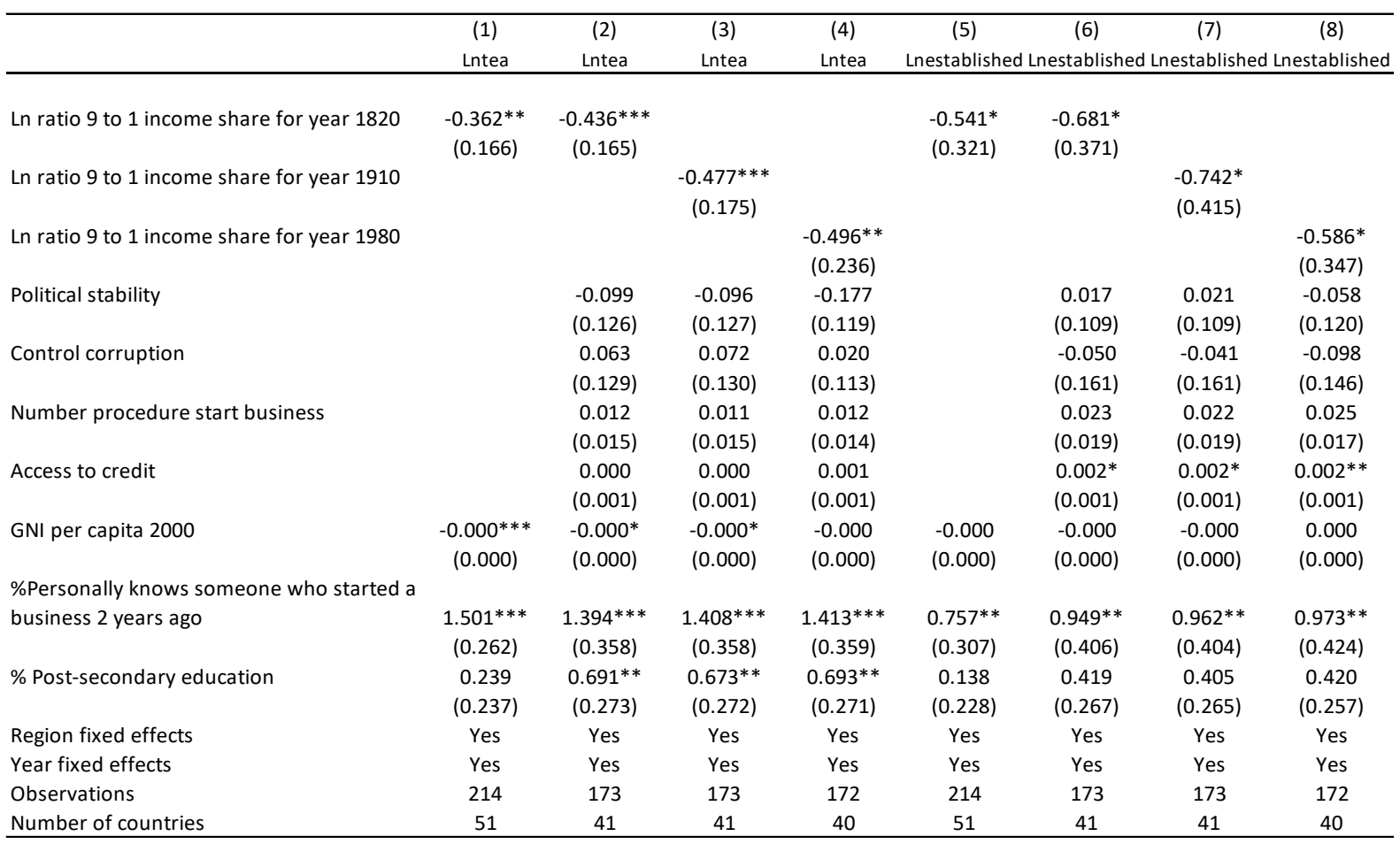

Notes: Robust standard errors in parentheses. Significance levels $* * * p<0.01,{ }^{* *} p<0.05,{ }^{*} p<0.1$

We do not re-run this analysis exclusively for Latin America given that we have historical indicators of inequality for very few countries in this region. Nonetheless, in Table 6, we restrict our analysis to only countries in the Global South; namely Africa, Latin America and Asia. Once again, we find a negative relationship between historical inequality and entrepreneurial activity, but higher than the one found for the full sample. Also, the regression coefficient for the inequality measure of 1820 is almost identical with the one in 1910 (the difference is tiny if show regression coefficients at the three decimal level). This is perhaps not surprising. Despite that during this period Latin America had undergone a process of independence from European colonisers, the reforms implemented by independent governments have not substantially reduced the high levels of inequality. Similarly, as mentioned earlier, Africa presented little changes in their income distribution for that period.

Around the globe, there was a decrease of inequality comparing 1980 to 1820 and to 1910. However, the Global South experienced the slowest decrease in inequality. This pattern 
might explain why Global South countries present an even stronger negative association between inequality in 1980 and the rate of percentage of people engaged in entrepreneurial activity at young and established firms than the one found for 1820 or $1910 .^{10}$

Table 6. Entrepreneurial activity during 2005-2011 and historical inequality for countries in Global South only, panel random effects

\begin{tabular}{|c|c|c|c|c|c|c|c|c|}
\hline & $(1)$ & $(2)$ & (3) & (4) & (5) & (6) & (7) & (8) \\
\hline & Lntea & Lntea & Lntea & Lntea & Lnestablished & Lnestablished & Lnestablished & Lnestablished \\
\hline Ln ratio 9 to 1 income share for year 1820 & $\begin{array}{c}-0.666 * * * \\
(0.244)\end{array}$ & $\begin{array}{c}-0.659 * * \\
(0.317)\end{array}$ & & & $\begin{array}{c}-1.436 * * * \\
(0.433)\end{array}$ & $\begin{array}{l}-1.751^{* * *} \\
(0.243)\end{array}$ & & \\
\hline Ln ratio 9 to 1 income share for year 1910 & & & $\begin{array}{c}-0.659 * * \\
(0.317)\end{array}$ & & & & $\begin{array}{l}-1.751^{* * *} \\
(0.243)\end{array}$ & \\
\hline Ln ratio 9 to 1 income share for year 1980 & & & & $\begin{array}{c}-0.906^{* * *} \\
(0.320)\end{array}$ & & & & $\begin{array}{l}-2.038^{* * *} \\
(0.289)\end{array}$ \\
\hline Political stability & & $\begin{array}{l}-0.194 \\
(0.122)\end{array}$ & $\begin{array}{l}-0.194 \\
(0.122)\end{array}$ & $\begin{array}{c}-0.256^{* *} \\
(0.106)\end{array}$ & & $\begin{array}{l}-0.128 \\
(0.162)\end{array}$ & $\begin{array}{l}-0.128 \\
(0.162)\end{array}$ & $\begin{array}{l}-0.179 \\
(0.160)\end{array}$ \\
\hline Control corruption & & $\begin{array}{c}0.029 \\
(0.116)\end{array}$ & $\begin{array}{c}0.029 \\
(0.116)\end{array}$ & $\begin{array}{c}0.026 \\
(0.103)\end{array}$ & & $\begin{array}{l}-0.079 \\
(0.157)\end{array}$ & $\begin{array}{l}-0.079 \\
(0.157)\end{array}$ & $\begin{array}{l}-0.012 \\
(0.155)\end{array}$ \\
\hline Number procedure start business & & $\begin{array}{c}0.019 \\
(0.023)\end{array}$ & $\begin{array}{c}0.019 \\
(0.023)\end{array}$ & $\begin{array}{c}0.018 \\
(0.023)\end{array}$ & & $\begin{array}{l}-0.003 \\
(0.024)\end{array}$ & $\begin{array}{l}-0.003 \\
(0.024)\end{array}$ & $\begin{array}{l}-0.004 \\
(0.024)\end{array}$ \\
\hline Access to credit & & $\begin{array}{l}-0.001 \\
(0.002)\end{array}$ & $\begin{array}{l}-0.001 \\
(0.002)\end{array}$ & $\begin{array}{l}-0.000 \\
(0.001)\end{array}$ & & $\begin{array}{l}-0.002 \\
(0.002)\end{array}$ & $\begin{array}{c}-0.002 \\
(0.002)\end{array}$ & $\begin{array}{c}-0.002 \\
(0.001)\end{array}$ \\
\hline GNI per capita 2000 & $\begin{array}{c}-0.000 * * \\
(0.000)\end{array}$ & $\begin{array}{l}-0.000 \\
(0.000)\end{array}$ & $\begin{array}{l}-0.000 \\
(0.000)\end{array}$ & $\begin{array}{l}-0.000 \\
(0.000)\end{array}$ & $\begin{array}{c}-0.000 * * * \\
(0.000)\end{array}$ & $\begin{array}{c}-0.000^{* * *} \\
(0.000)\end{array}$ & $\begin{array}{c}-0.000 * * * \\
(0.000)\end{array}$ & $\begin{array}{c}-0.000^{* * *} \\
(0.000)\end{array}$ \\
\hline $\begin{array}{l}\text { \%Personally knows someone who started a } \\
\text { business } 2 \text { years ago }\end{array}$ & $1.081^{* *}$ & 0.888 & 0.888 & $0.988^{*}$ & $-0.849 *$ & -0.619 & -0.619 & -0.260 \\
\hline & $(0.445)$ & $(0.592)$ & $(0.592)$ & $(0.591)$ & $(0.489)$ & $(0.726)$ & $(0.726)$ & $(0.720)$ \\
\hline$\%$ Post-secondary education & $\begin{array}{c}0.355 \\
(0.356)\end{array}$ & $\begin{array}{l}0.672^{*} \\
(0.404)\end{array}$ & $\begin{array}{l}0.672 * \\
(0.404)\end{array}$ & $\begin{array}{l}0.720^{*} \\
(0.390)\end{array}$ & $\begin{array}{l}-0.038 \\
(0.516)\end{array}$ & $\begin{array}{c}0.301 \\
(0.547)\end{array}$ & $\begin{array}{c}0.301 \\
(0.547)\end{array}$ & $\begin{array}{c}0.441 \\
(0.535)\end{array}$ \\
\hline Region fixed effects & Yes & Yes & Yes & Yes & Yes & Yes & Yes & Yes \\
\hline Year fixed effects & Yes & Yes & Yes & Yes & Yes & Yes & Yes & Yes \\
\hline Observations & 113 & 81 & 81 & 80 & 113 & 81 & 81 & 80 \\
\hline Number of countries & 33 & 24 & 24 & 23 & 33 & 24 & 24 & 23 \\
\hline
\end{tabular}

Notes: Robust standard errors in parentheses. Significance levels $* * * p<0.01,{ }^{* *} p<0.05,{ }^{*} p<0.1$

Our second robustness check aims at assessing the extent our measure of historical income inequality captures the inequalities in access to the credit market between the rich and the poor, which has been argued as the mechanism through which income inequality affects

\footnotetext{
${ }^{10}$ For instance the Gini coefficient measure went down from 0.47 in 1820 to 0.41 in 1980 across all the sample analysed. During that period, the Gini coefficient also declined in the Global South, albeit only very slightly from 0.49 to 0.48 .
} 
entrepreneurial activity over time. To the best of our knowledge, there are no historical estimators on access to credit by income groups across countries. There is scant evidence on this even for the latest decades. Thus, we use the recently released data on Financial Inclusion by the World Bank. This dataset shows the percentage of loans given in the previous year to the highest $60 \%$ income richest group and the bottom $40 \%$ income poorest group. This information is only available for 49 of the countries for which we also have historical indicators of income distribution, and unfortunately only have information for 2011 (the last year for which the GEM survey is publically accessible). Bearing in mind these limitations, in Table 7, we show that on average, roughly the same percentage of rich and poor people received a loan in the previous year, but with important differences across countries.

Table 7. Summary statistics on financial inclusion for 2011

\begin{tabular}{lccccc}
\hline & Obs & Mean & Std. Dev. & Min & Max \\
\hline Loan in the past year & 49 & 31.11 & 11.37 & 13.39 & 71.06 \\
Loan in the past year, income, richest 60\% & 49 & 31.22 & 12.10 & 14.22 & 71.23 \\
Loan in the past year, income, poorest 40\% & 49 & 30.99 & 11.52 & 11.11 & 70.82 \\
\hline
\end{tabular}

Moreover, Figure 3 shows a positive relationship between the ratio of loans given to the richest and poorest income groups for 2011 and the ratio of top $9^{\text {th }}$ decile to bottom decile for 1820. This association suggests that the more unequal countries were in the distant past, the more unequal the access to credit today.

Figure 3. 2011 Ratio of loans given during previous year to richest $60 \%$ to poorest $40 \%$ and ratio of the income share top 9 decile to the bottom decile for year 1820 


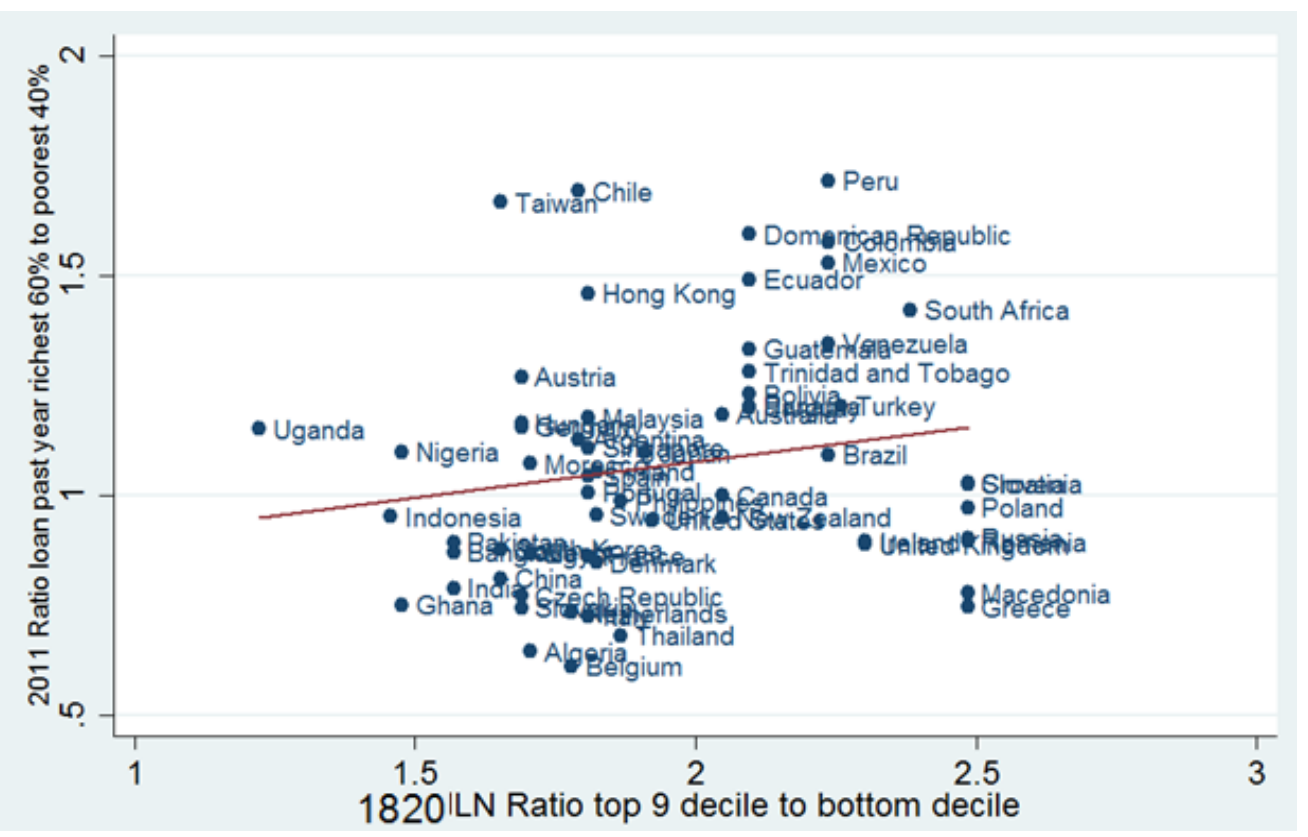

To test whether these current indicators of access to credit have any impact on entrepreneurial activity in Table 8, we re-ran our analysis including in columns (1) and (3) the percentage of richest $60 \%$ and poorest $40 \%$ that got a loan in the previous year. As expected, there is a positive and statistically significant relationship between the entrepreneurial activity (for young and established firms) and the percentage of poor people that have loans in the previous year. That is, a less credit constrained poor population produces a higher percentage of young and established firms. In contrast, there is a negative relationship between entrepreneurial activity and the credit given to the richest $60 \%$. Since the theoretical predictions of the different access to credit on firms' development refer to the ratio of people that are credit and not credit constrained, column (2) and (4) instead use the log of the ratio of the loan given to the richest $60 \%$ to poorest $40 \%$. The coefficient of this ratio reveals, once again as expected, a negative association between entrepreneurial activity and the ratio of loans given to the wealthy to the poor, just as we have found before for the various historical measures of inequality. However, this relationship is statistically significant only for the log of young businesses and not for established ones. This suggests that higher levels of financial inclusion, 
meaning a higher proportion of loans given to the poorest groups, would be beneficial for entrepreneurial activity, particularly for creating new firms. However, other policies will be needed for the poorest groups to be able to have their businesses mature, such as broader access to credit for firms to be able to survive.

Table 8. Entrepreneurial activity during 2005-2011 and alternative access to credit measures, panel random effects

\begin{tabular}{lcccc}
\hline & $(1)$ & $(2)$ & $(3)$ & $(4)$ \\
& Lntea & Lntea & Lnestablished & Lnestablished \\
\hline & & & & \\
Ln ratio 9 to 1 income share for year 1820 & $-0.311^{* *}$ & $-0.296^{*}$ & $-0.655^{* *}$ & $-0.573^{*}$ \\
& $(0.144)$ & $(0.156)$ & $(0.288)$ & $(0.328)$ \\
Political stability & $-0.171^{* *}$ & $-0.169^{* *}$ & -0.120 & -0.122 \\
& $(0.080)$ & $(0.083)$ & $(0.105)$ & $(0.106)$ \\
Control corruption & 0.057 & 0.090 & -0.011 & 0.057 \\
& $(0.082)$ & $(0.094)$ & $(0.141)$ & $(0.141)$ \\
Number procedure start business & 0.012 & 0.013 & 0.016 & 0.018 \\
& $(0.012)$ & $(0.013)$ & $(0.018)$ & $(0.019)$ \\
GNI per capita 2000 & $-0.000^{* *}$ & $-0.000^{* *}$ & -0.000 & -0.000 \\
& $(0.000)$ & $(0.000)$ & $(0.000)$ & $(0.000)$ \\
\%Personally knows someone who started & & & & \\
a business 2 years ago & $1.683^{* * *}$ & $1.786^{* * *}$ & $0.883^{*}$ & $1.080^{* *}$ \\
& $(0.314)$ & $(0.324)$ & $(0.496)$ & $(0.515)$ \\
\% Post-secondary education & $0.522^{* *}$ & $0.546^{* *}$ & 0.097 & 0.118 \\
& $(0.245)$ & $(0.245)$ & $(0.302)$ & $(0.300)$ \\
Loan in the past year richest 60\% & $-0.019^{* *}$ & & $-0.022^{*}$ & \\
& $(0.008)$ & & $(0.012)$ & \\
Loan in the past year poorest 40\% & $0.026^{* * *}$ & & $0.042^{* * *}$ & \\
& $(0.009)$ & & $(0.014)$ & \\
In ratio of loan richest to poorest & & $-0.507^{*}$ & & -0.598 \\
Region fixed effects & & $(0.261)$ & & $(0.401)$ \\
Year fixed effects & Yes & Yes & Yes & Yes \\
Observations & Yes & Yes & Yes & Yes \\
Number of countries & 196 & 196 & 196 & 196 \\
\hline & 47 & 47 & 47 & 47 \\
\hline
\end{tabular}

Notes: Robust standard errors in parentheses. Significance levels $* * * p<0.01,{ }^{* *} p<0.05, * p<0.1$

5.1 Instrumental variables: Determinants of current institutions 
The great majority of previous empirical studies similar to ours have not tested for the potential endogenous relationship between entrepreneurial activity and institutional variables. ${ }^{11}$ Thus, based on previous empirical literature, we have a priori no certainty on whether our results presented thus far could be biased. As our third and last robustness check, we test for endogeneity between entrepreneurial activity and our institutional variables in a two-stage process. In the first stage, we estimate the relationship between current credit and institutions, the potential endogenous covariates so far used, and external instruments as shown in eq. (2). External instrument $Z_{\mathrm{i}}$ denotes a set of dummy variables indicating the former coloniser, whether Spain, Great Britain or France, and instruments frequently used in the literature (La Porta, 1998, 1999). In addition, we use the European settler mortality rate during the colonizer era, used by Acemoglu et al. (2001). These instruments are likely good candidates to measure how inclusive the institutions have been over time influencing political stability, control of corruption and entrepreneurial environment. $Z_{i t}$ denotes the external instruments that vary over time within countries. Among these, we include the number of journalists killed by country ${ }^{12}$ and year from 2005-2011 given that previous studies have found the degree of freedom of media is strongly correlated with control of corruption and with political stability (Besley and Burgess, 2001; Besley and Prat, 2006; Chowdhury, 2004). We also consider the fixed telephone subscriptions per 100 people as previous studies have found it associated with financial inclusion (Beck et al., 2007). In addition, we use the average systolic blood pressure by country and year, as according to recent literature, people who find it hard to gain access to credit can experience physiological responses to stress. For instance, people experiencing

\footnotetext{
${ }^{11}$ An exception is found in Ardanga and Lusardi (2008), in which business regulations are instrumented with the countries’ legal origin to assess endogeneity between entrepreneurship and credit regulation. In that study, as to some extent ours, find no evidence of endogeneity.

${ }^{12}$ Data obtained from CPJ (2017).
} 
financial distress are less likely to follow recommended health maintenance practices such as eating a healthy diet, thus elevating blood pressure and risk of cardiovascular diseases and cholesterol (O’Neil et al., 2005). Since cardiovascular diseases, high blood pressure and cholesterol are associated with economic development, they vary across countries, making them ideal instruments since institutions and credit vary across countries (Ezzati et al., 2005).

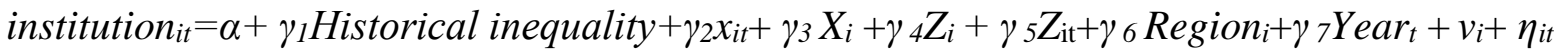

Table A.5 in Appendix shows the results of the first-stage regressions for each of the four instrumented institutional variables: political stability, control of corruption, the number of procedures to start a new business and access to credit.

Table A.6 then presents the results of the instrumental variable (IV)-second stage least squares of the regression shown in eq. (3). There, we also include the Anderson-Rubin Wald Join test of all instruments, which confirms that the instruments are jointly correlated with the endogenous variable and are valid instruments. The Sargan statistics suggest the instruments are valid, that is uncorrelated with the error term, and the excluded instruments are correctly excluded from the main panel random effects (Baum, 2006).

$$
y_{i t}=\alpha+\beta_{1} \text { Historicalinequality }+\beta_{2} X_{i t}+\beta_{3} X_{i}+\beta_{4} \text { Region }_{i}+\beta_{5} \text { Year }_{t}+\beta_{6} \text { inst } \widehat{\text { itut }} \text { ons }+u_{i}+\varepsilon_{\text {it }}
$$

The endogeneity test confirms the presence of endogeneity when considering the current institutions for young business but not for the established firms. Despite the mixed evidence of the endogeneity test, the second-stage regressions suggest that current institutions have no impact on the proportion of people involved in entrepreneurial activity, as shown in the previous results. Moreover, these IV regressions confirm the hypothesis that inequality is negatively associated with entrepreneurial activity. A higher ratio of wealthy to poor people in 
1820 produces a lower proportion of people engaged in young or established firms during 2005-2011 (Table A.5, columns 1 and 2). ${ }^{13}$

Given that none of the instrumented current institutions turned statistically significant, and the mixed evidence of the presence of endogeneity, our preferred estimates remain the panel country random effects presented earlier.

\section{Conclusion}

The aim of this article was to empirically test whether income inequality has any long-term effect on entrepreneurship, thereby affecting development over time. To this end, we used a panel of 66 countries from 2005-2011 using the Global Entrepreneurship Monitor (GEM) survey. We triangulated this survey with current institutional indicators, access to financial markets and with the estimates of income distribution around the globe from the 19th to 20th century provided by Bourguignon and Morrisson (2002).

We draw two main conclusions from our results. First, high levels of historical inequality in the long-run are associated with a high percentage of people reporting opening

\footnotetext{
${ }^{13}$ We re-ran all our IV regressions using the different historical inequality measures so far presented showing very similar results, but for simplification purposes, we only present those for 1820 and the ratio of the 9 decile to the bottom decile. We also tried other combinations of instruments, such as the percentage of the population with access to mobile, internet, the percentage of media owned by the state, and the legal origin of counties' legal code. All these instruments resulted in similar results but turned out to be weaker than the instruments thus far presented. We also tried to instrument only one institutional variable at a time, whilst leaving the rest out of the regression resulting once again in similar results. There is a negative association between historical inequality and entrepreneurial activity and no evidence that the current institutional environment affects much the creation and maturity of firms.
} 
business out of need. This result is fully compatible with the empirical observation that regions that today are highly unequal, such as Latin America, also have high levels of early-stage businesses and informal economy. Second, since these young businesses are unlikely to survive in the short run, we find that income inequality prevailing in the distant past has overall a negative effect on the creation and survival of businesses over time. These results are consistent regardless of the different measures of inequality (whether the Gini index or different ratios of income share) for different years (1820, 1910 or 1980), whether removing regions that are highly unequal from the analysis, or focusing only on the Global South. The results are also robust if using instrumental variables to deal for the potential endogeneity between the institutional variables used and the entrepreneurial activity assessed.

Our results then give support to the theoretical literature that suggests that if the early wealth/income distribution is such that a large percentage of the population is credit constrained, then fewer businesses will be created and survive over time (Banerjee and Newman, 1993; Ghatak and Jiang, 2002). Moreover, our findings might help reconcile the mixed evidence of previous studies that suggest high levels of inequality increase early entrepreneurial activity (Lippman et al., 2005; Naudé, 2010) as well as that of Halter et al. (2014) who find inequality helps economic performance in the short term, but has an overall negative effect in the long term. Our findings also support recent articles concerned about the damaging effects that inequality has in the long-run, particularly given the rise of inequality in developed countries seen over the last four decades (Dabla-Norris et al., 2015; Piketty, 2015; Stiglitz, 2012; 2015).

Our results have important policy implications. Our findings suggest economic convergence across countries is unlikely to occur since countries are predisposed to their initial conditions for their businesses to thrive and in others to struggle. Thus, to foster the creation of businesses, policies should focus on addressing long-standing differences in wealth within 
countries as well as fostering financial inclusion among the poor. Incidentally, these policies could well foster convergence across countries as well, which is an issue that deserves further research.

\section{References}

Acemoglu, D., Johnson, S. and Robinson, J. 2001. “The colonial origins of comparative development: An empirical investigation,” American Economic Review, 91(5): 1369-1401.

Acemoglu, D. and Robinson, J. 2010. "Why is Africa poor?” Economic History of Southern Africa, 25(1): 21-50.

Aghion, P. and Bolton, P. 1997. “A theory of trickle-down growth and development,” The Review of Economic Studies, 64(2): 151-172.

Aghion, P., Caroli, E., and Garcia-Penalosa, C. 1999. "Inequality and economic growth: The perspective of the new growth theories,” Journal of Economic Literature, 37(4): 1615-60.

Aldrich, H. E. and Fiol, M. C. 1994. "Fools rush in? The institutional context of industry creation,” Academy of Management Review, 19(4): 645-670.

Aldrich. H. E. 1999. Organizations Evolving, London: Sage.

Alesina, A. and Perotti, R. 1996. "Income distribution, political instability, and investment,” European Economic Review, 40(6): 1203-1228.

Alesina, A. and Rodrick, D. 1994. "Distributive politics and economic growth,” The Quarterly Journal of Economics, 109(2): 465-490.

Alvarez, C. and Urbano, D. 2011. "Environmental factors and entrepreneurial activity in Latin America,” Academia Revista Latinoamericana de Administración, 48: 126-139. 
Ardagna, S. and Lusardi, A. 2008. "Explaining international differences in entrepreneurship: The role of individual characteristics and regulatory constraints,” NBER Working Paper 14012.

Audretsch, D. B., Keilbach, M. C., and Lehmann, E. E. 2006. Entrepreneurship and Economic Growth. New York: Oxford University Press.

Baliamoune-Lutz, M., Brixiová, Z. and Ndikumana, L. 2011. “Credit constraints and productive entrepreneurship in Africa. Political Economy Research Institute.” Working Paper No. 276.

Banerjee, A. and Newman, A. F. 1993. "Occupational choice and the process of development,” Journal of Political Economy, 101 (2): 274-298.

Baum, C.F. 2006. An Introduction to Modern Econometrics Using Stata. College Station, TX: Stata Press.

Baumol, W. J., Litan, R.E. and Schramm, C. J. 2007. Good capitalism, bad capitalism, and the economics of growth and prosperity. Yale University Press, New Haven, CT.

Beck, T., Demirguc-Kunt, A. and Martinez Peria, M. 2007. "Reaching out: Access to and use of banking services across countries,” Journal of Financial Economics, 85(1): 234266.

Bénabou, R. 1996. Inequality and Growth, in NBER Macroeconomics Annual. Ben Bernanke and Julio Rotemberg, eds. London and Cambridge: MIT Press, pp. 11-7.

Berg, E. 2013. “Are poor people credit-constrained or myopic? Evidence from a South African panel,” Journal of Development Economics, 101(2): 195-205.

Besley, T. and Burgess, R. 2001. "Political agency, government responsiveness and the role of the media,” European Economic Review, 45(4-6): 629-640.

Besley, T. and Prat, A. 2006. "Handcuffs for the grabbing hand? Media capture and government accountability,” American Economic Review, 96(3): 720-736. 
Bourguignon, F. and Morrisson, C. 2002. “Inequality among world citizens: 18201992,” American Economic Review, 92(4): 727-744.

Champernowne, D.G. 1953. “A model of income distribution,” The Economic Journal, 63(250): 318-351.

Chowdhury, S. K. 2004. “The effect of democracy and press freedom on corruption: An empirical test,” Economic Letters 85(1), 93-101.

Cingano, F. 2014. "Trends in income inequality and its impact on economic growth," OECD Social, Employment and Migration, Working papers, No. 163. OECD Publishing. Committee to Protect Journalists (CPJ). 2017. Journalists killed since 1992 database, Retrieved from https://cpj.org/killed

Dabla-Norris, E., Kochhar, K., Suphaphiphat, N., Ricka, F. and Tsounta, E. 2015. “Causes and consequences of income inequality: A global perspective,” IMF Staff Discussion Note SDN/15/13.

De Dominicis, L. De Groot, H. and Florax, R. 2006. “Growth and inequality: A metaanalysis,” Tinbergen Institute Discussion Paper, No. 2006-064/3.

Engerman, S. and Sokoloff, K. 2005. “Colonialism, inequality and long-run paths of development,” National Bureau of Economic Research, working paper 11057.

Evans, D. and Jovanovic, B. 1989. “An estimated model of entrepreneurial choice under liquidity constraints,” Journal of Political Economy, 97(4): 808-827.

Ezzati, M., Vander Hoorn, S., Lawes, C., Leach, R., James, W., Lopez, A., Rodgers, A. and Murray, C. 2005. “Rethinking the 'Diseases of affluence’, Paradigm: Global Patterns of Nutritional Risks in Relation to Economic Development,” PLoS Med, 2(5): 404-412.

Fairlie, R, and Krashinsky, H.A. 2012. "Liquidity constraints, household wealth, and entrepreneurship revisited,” Review of Income and Wealth, 58(2): 279-306. 
Frid, C. J., Wyman, D. and Coffey, B. 2016. "Effects of wealth inequality on entrepreneurship,” Small Business Economics, 47(4): 895-920.

Galor, O. and Moav. O. 2004. "From physical to human capital accumulation: Inequality and the process of development,” Review of Economic Studies, 71(4):1001-1026.

Galor, O. and Zeira, J. 1993. "Income distribution and macroeconomics,” Review of Economic Studies, 60(1): 35-52.

Gentry, W. M., and Hubbard, R. G. 2004. "Entrepreneurship and household saving,” Advances in Economic Analysis and Policy, 4(1):1-55.

Ghatak, M. and Jiang, N.H. 2002. “A simple model of inequality, occupational choice and development,” Journal of Development Economics, 69(1): 205-226.

Glaeser, E., La Porta, R., Lopez-de-Silanes, F. and Shleifer, A. 2004. “Do institutions cause growth?” Journal of Economic Growth, 9(3): 271-303.

Glaeser, E., Scheinkman, J., Shleifer, A. 2003. “The injustice of inequality,” Journal of Monetary Economics, 50(1): 199-222.

Halter, D., Oeschslin, M. and Zweimüller, M. 2014. "Inequality and growth: The neglected time dimension,” Journal of Economic Growth, 19(1): 81-104.

Holtz-Eakin, D.D., Joulfaian, D. and Rosen, H.D. 1994. "Sticking it out: Entrepreneurial survival and liquidity constraints,” Journal of Political Economy, 102(1): 5375.

Hurst, E. and Lusardi, A. 2004. "Liquidity constraints, household wealth, and entrepreneurship,” Journal of Political Economy, 112(3): 319-347.

Jaramillo, F. 1995. “Distribution du revenue, composition de la demande et croissance, ” MAD, Université de Paris I, mimeo. 
Kaufmann, D., Kraay, A. and Mastruzzi, M. 2010. “The worldwide governance indicators: Methodology and analytical issues,” World Bank Policy Research Working Paper No. 5430.

Keister, L. A. 2000. Wealth in America, New York: Cambridge University Press.

Krueger, N.F. 1993. “The Impact of Prior Entrepreneurial Exposure on Perceptions and New Venture Feasibility and Desirability,” Entrepreneurship Theory and Practice, 18(1): 521.

La Porta, R., Lopez-de-Silanes, F., Shleifer, A. and Vishny, R.W. 1998. "Law and finance,” Journal of Political Economy, 106(6): 1113-1155.

La Porta, R., Lopez-de-Silanes, F., Shleifer, A. and Vishny, R.W. 1999. “The quality of government,” Journal of Law, Economics and Organization, 15(1): 222-279.

Lecuna, A. 2014. "High income inequality as a structural factor in entrepreneurial activity,” Journal of Technology Management \& Innovation, 9(1):13-26.

Lippmann, S., Davis, A., and Aldrich, H. E. 2005. "Entrepreneurship and Inequality,” in Lisa A. Keister (ed.) Entrepreneurship (Research in the Sociology of Work, Volume 15) Emerald Group Publishing Limited, pp.3-31.

Ljungqvist, L. 1993. "Economic underdevelopment: The case of a missing market for human capital,” Journal of Development Economics, 40(2): 219-239.

Man, T., Lau, T. and Chan, K.F. 2002. "The competitiveness of small and medium enterprises. A conceptualization with focus on entrepreneurial competencies," Journal of Business Venturing, 17(2):123-142.

Mehmetoglu, M. and Jakobsen G. 2017. Applied statistics using stata: A guide for the social sciences. Ed. Sage Publications.

Mesnard, A. and Ravallion, M. 2001. “Is inequality bad for business?” Policy Research Working Paper 2527, World Bank. 
Michalopoulos, S. and Papaioannou, E. 2011. “The Long-Run Effects of the Scramble for Africa,” CEPR Discussion Paper No. 8676.

Murphy, K., Shleifer, A. and Vishny, R. 1989. “Income Distribution, Market Size, and Industrialization,” Quarterly Journal of Economics, 104(3): 537-564.

Naudé, W. 2008. “Entrepreneurship in economic development.” UNU-Wider Research Paper No. 2008/20.

Naudé, W. 2010. “Entrepreneurship, developing countries, and development economics: new approaches and insights,” Small Business Economics, 34(1): 1-12.

O’Neill, B., Sorhaindo, B., Xiao, J. J. and Garman, E. T. 2005. "Health, financial wellbeing, and financial practices of financially distressed consumers,” Consumer Interests Annual $51,80-82$.

Ordeñaga, X. and Arteaga, E. 2012. "Middle-Class Entrepreneurship and the Effect of Social Capital,” IADB WP No. 318.

Perotti, R. 1996. "Growth, income distribution and democracy: What the data say," Journal of Economic Growth, 1(2): 149-87.

Persson, T. and Tabellini, G. 1994. "Is inequality harmful for growth,” The American Economic Review, 84(3): 600-621.

Piketty, T. 2015. "Putting distribution back at the center of economics," Journal of Economic Perspectives, 29(1): 67-88.

Piketty, T. and Saez, E. 2006. "The evolution of top incomes: A historical and international perspective,” American Economic Review, 96(2): 200-205.

Quadrini, V. 1999. “The importance of entrepreneurship for wealth concentration and mobility,” Review of Income and Wealth, 45(1): 1 -19.

Rapoport, H. 2002. "Migration, credit constraints and self-employment: A simple model of occupational choice, inequality and growth,” Economics Bulletin, 15(7) 1-5. 
Reynolds, P., Bosma, N., Autio, E., Hunt, S., De Bono, N., Servais, I. and LopezGarcia, P. 2005. “Global entrepreneurship monitor: data collection design and implementation 1998-2003,” Small Business Economics, 24(3): 205-31.

Reynolds, P. D., Camp, S. M., Bygrave, W. D., Autio, E. and Hay, M. 2001. “Global Entrepreneurship Monitor. 2001 Executive report,” Kansas City: Kauffman Center for Entrepreneurial Learning.

Rosenzweig, M. R. and Hans P. Binswanger, H. P. 1993. "Wealth, Weather Risk and the Composition and Profitability of Agricultural Investments" The Economic Journal, 103(416): 56-78.

Shapero, A. and Sokol, L. 1982. “Social Dimensions of Entrepreneurship.” In: Kent C, Sexton D, Vesper K (eds.), The Encyclopedia of Entrepreneurship, Prentice-Hall, Englewood Cliffs, pp. 72-90.

Schumpeter, J. 1943. Capitalims, Socialism and Democracy. London: Allen and Unwin.

Simón-Moya, V., Revuelto-Taboada, L. and Fernández-Guerrero, R. 2014. "Institutional and economic drivers of entrepreneurship: An international perspective," Journal of Business Research, 67(5):715-721.

Solimano, A. 2014. Entrepreneurship, The Middle Class, and Social Mobility: An Overview of Literature, in Entrepreneurship in Latin America: A step up the social ladder?, edited by Lora, E. and Castellani, F.; Interamerican Development Bank and World Bank.

Stiglitz, J. 2012. The Price of Inequality: How Today’s Divided Society Endangers Our Future. W.W. Norton, New York, NY.

Stiglitz, J. 2015. “The origins of inequality, and policies to contain it,” National Tax Journal, 68(2), 425-448. 
Voitchovsky, S. 2009. “Inequality and Economic Growth,” in Wiemer Salverda, Brian Nolan, and Tim Smeeding (eds). The Oxford Handbook of Economic Inequality. Oxford, OUP.

Wennekers, S., van Stel, A., Thurik, R. and Reynolds, P. 2005. "Nascent entrepreneurship and the level of economic development," Small Business Economics, 24(3): 293-309.

Zissimopoulos, J., Karoly, L. and Gu, Q. 2009. “Liquidity constraints, household wealth and self-employment: The case of older workers,” RAND working paper series.

\section{Appendix}

Table A.1. List of countries and country groups for which Bourgignon and Morrison (2002) estimated historical inequality indicators 
Africa

Cote d'Ivoire, Ghana, Kenya, Egypt, Nigeria, North Africa, South Africa and 46 other grouped African countries

Asia

China, India, Bangladesh, Burma, Pakistan, Thailand, Philippines and 45 other grouped Asian countries

Japan, Korea, Taiwan

Japan, Korea and Taiwan

Latin America

Brazil, Mexico, Colombia, Peru, Venezuela and 37 other grouped Latin American countries

\section{Easter Europe}

Bulgaria, Greece, Romania, Yugoslavia, Poland, Russia and Turkey

\section{Western Europe and European offshoots}

Argentina, Chile, Australia, Canada, New Zealand, Austria, Czechoslovakia, Hungary, France, Germany, Italy Scandinavian countries, Spain, Portugal, Switzerland, Benelux, and microstates,

United Kingdom, Ireland and United States

Table A.2. List of countries analysed in GEM and years sampled 


\begin{tabular}{|c|c|c|c|}
\hline Country & Years & Country & Years \\
\hline Algeria & 2009 & Malaysia & $2006,2009,2010,2011$ \\
\hline Algeria & 2011 & Mexico & $2005-2011$ \\
\hline Argentina & $2005-2011$ & Morocco & 2009 \\
\hline Australia & 2005-2011 & Netherlands & 2005-2011 \\
\hline Austria & 2005,2006 & New Zealand & 2005 \\
\hline Bangladesh & 2011 & Nigeria & 2011 \\
\hline Belgium & $2005-2011$ & Norway & 2005-2011 \\
\hline Bolivia & 2008,2009 & Pakistan & $2010-2011$ \\
\hline Brazil & 2005-2011 & Panama & 2009, 2011 \\
\hline Canada & 2005,2006 & Peru & $2006-2011$ \\
\hline Chile & $2005-2011$ & Philippines & 2006 \\
\hline China & $2005-2011$ & Poland & 2011 \\
\hline Colombia & $2006-2011$ & Portugal & 2007, 2010, 2011 \\
\hline Croatia & $2005-2011$ & Romania & 2007-2011 \\
\hline Czech Republic & 2006,2011 & Russia & $2006-2011$ \\
\hline Denmark & $2005-2011$ & Singapore & $2005,2006,2011$ \\
\hline Dominican Republic & 2007, 2008, 2009 & Slovakia & 2011 \\
\hline Ecuador & $2008,2009,2010$ & Slovenia & $2005-2011$ \\
\hline Egypt & 2008,2010 & South Africa & $2005-2011$ \\
\hline Finland & $2005-2011$ & South Korea & $2008-2011$ \\
\hline France & $2005-2011$ & Spain & $2005-2011$ \\
\hline Germany & $2005-2011$ & Sweden & 2005, 2006, 2007, 2010, 2011 \\
\hline Ghana & 2010 & Switzerland & 2005, 2007, 2009, 2010, 2011 \\
\hline Greece & 2005-2011 & Taiwan & 2010, 2011 \\
\hline Guatemala & 2009, 2010, 2011 & Thailand & 2005, 2006, 2007, 2011 \\
\hline Hong Kong & 2007, 2009 & Trinidad and Tobago & 2010, 2011 \\
\hline Hungary & $2005-2011$ & Tunisia & 2009,2010 \\
\hline Iceland & 2005-2011 & Turkey & $2006-2011$ \\
\hline India & 2006, 2007, 2008 & Uganda & 2009,2010 \\
\hline Indonesia & 2006 & United Kingdom & $2005-2011$ \\
\hline Ireland & $2005-2011$ & United States & $2005-2011$ \\
\hline Italy & $2005-2010$ & Uruguay & $2006-2011$ \\
\hline Japan & $2005-2011$ & Venezuela & 2005, 2007, 2009, 2011 \\
\hline Macedonia & 2008,2010 & & \\
\hline
\end{tabular}

Table A.3. Data description and sources 


\begin{tabular}{|c|c|c|}
\hline Data descriptions and sources & Description & Source \\
\hline$\%$ Young firms (TEA) & $\begin{array}{l}\text { Percentage of adults aged } 18 \text { and over setting up a business or owning-managing a young firm (up to } 3.5 \\
\text { years old) including self-employment (Reynolds et al., 2005). }\end{array}$ & GEM 2005 to 2011 \\
\hline \%Established firms & $\begin{array}{l}\text { Percentage of adults aged } 18 \text { and over that owns and manages an established firm (older than } 3.5 \text { years } \\
\text { old) including self-employment (Reynolds et al., 2005). }\end{array}$ & GEM 2005 to 2011 \\
\hline $\begin{array}{l}\text { \% Personally knows someone who started a } \\
\text { business } 2 \text { years ago }\end{array}$ & $\begin{array}{l}\text { Percentage of individuals who know someone personally who started a business in the past years } \\
\text { (Reynolds et al., 2005). }\end{array}$ & GEM 2005 to 2011 \\
\hline$\%$ Have post-secondary education & $\begin{array}{l}\text { Percentage of individuals who have post-secondary or higher education. } \\
\text { Political stability and absence of violence estimates the probability that the government will be }\end{array}$ & GEM 2005 to 2011 \\
\hline Political stability & $\begin{array}{l}\text { destabilized or overthrown by unconstitutional or violent means, including politically-motivated violence } \\
\text { and terrorism. Ranges from - } 2.5 \text { (weak) to } 2.5 \text { (strong). (Kaufmann et al., 2010) }\end{array}$ & WGI 2005-2011 \\
\hline Control of corruption & $\begin{array}{l}\text { Control of corruption estimates perceptions of the extent to which public power is exercised for private } \\
\text { gain, including both petty and grand forms of corruption, and capture of the estate by elites and private } \\
\text { interests. This variable rantes between }-2.5 \text { to } 2.5 \text { with higher outcomes corresponding to better } \\
\text { outcomes of institutions (Kaufmann et al., 2010). }\end{array}$ & WGI 2005-2011 \\
\hline Number of procedures starting a business & $\begin{array}{l}\text { Number of procedures that are officially required for an entrepreneur to start up and formally operate an } \\
\text { industrial or commercial business and the duration of these procedures. }\end{array}$ & $\begin{array}{l}\text { World Bank Doing Business, } \\
\text { 2005-2011 }\end{array}$ \\
\hline Access to credit & $\begin{array}{l}\text { Domestic credit indicator provided by the banking sector which include all credit to various sectors as } \\
\text { percentage of GDP. }\end{array}$ & World Bank 2001-2011 \\
\hline GNI per capita in 2000 & Gross National Income per capita in 2000. & World Bank 2000 \\
\hline Income share for years $1700,1810,1910,1980$ & $\begin{array}{l}\text { Estimates of income shares by decile for years } 1700,1810,1910 \text {, also used to estimate Gini coefficients for } \\
\text { these years. }\end{array}$ & $\begin{array}{l}\text { Bourguignon and Morrisson } \\
\text { (2002) and Morrisson and } \\
\text { Murtin (2011) }\end{array}$ \\
\hline Journalist killed & Number of journalist killed by country. & CPJ 2005-2011 \\
\hline Blood pressure male & Systolic blood pressure of men $(\mathrm{mm} \mathrm{Hg})$ age standardized mean. & WHO 2005-2011 \\
\hline Fixed telephone subscriptions (per 100 people) & $\begin{array}{l}\text { Fixed telephone subscriptions refers to the sum of active number of analogue fixed telephone lines, voice- } \\
\text { over-IP (VoIP) subscriptions, fixed wireless local loop (WLL) subscriptions, ISDN voice-channel equivalents } \\
\text { and fixed public payphones. }\end{array}$ & World Bank 2001-2011 \\
\hline European settler mortality & $\begin{array}{l}\text { Mortality rates of soldiers, bishops, and sailors stationed in the colonies between the seventeenth and } \\
\text { nineteenth centuries, largely based on the work of Philip D. Curtin, used by Acemoglu et al., (2001) as } \\
\text { instrument of mortality rates faced by settlers. }\end{array}$ & Acemoglu et al., (2001) \\
\hline Colonial dummy & $\begin{array}{l}\text { Dummy indicated whether country was a British, French, German, Spanish, Italian, Belgian, Dutch or } \\
\text { Portuguese colony. }\end{array}$ & La Porta et al., 1999 \\
\hline Loan in the past year & $\begin{array}{l}\text { Denotes the percentage of respondents who borrowed any money in the past } 12 \text { months from any of the } \\
\text { following sources: a formal financial institution, a store by using instalment credit, family or friends, } \\
\text { employer, or another private lender (\% age } 15+\text { ). Available only for } 2011 \text {. }\end{array}$ & World Bank 2011 \\
\hline Loan in the past year, income, richest $60 \%$ & $\begin{array}{l}\text { Denotes the percentage of respondents who borrowed any money in the past } 12 \text { months from any of the } \\
\text { following sources: a formal financial institution, a store by using instalment credit, family or friends, } \\
\text { employer, or another private lender (income, richest } 60 \% \text {, } \% \text { age } 15+\text { ). Available only for } 2011 \text {. }\end{array}$ & World Bank 2011 \\
\hline Loan in the past year, income, poorest $40 \%$ & $\begin{array}{l}\text { Denotes the percentage of respondents who borrowed any money in the past } 12 \text { months from any of the } \\
\text { following sources: a formal financial institution, a store by using instalment credit, family or friends, } \\
\text { employer, or another private lender (income, poorest } 40 \%, \% \text { age } 15+\text { ). Available only for } 2011 \text {. }\end{array}$ & World Bank 2011 \\
\hline
\end{tabular}


Table A.4. Entrepreneurial activity during 2005-2011 and alternative historical inequality measure, panel random effects

\begin{tabular}{lcccc}
\hline & $\begin{array}{c}(1) \\
\text { Lntea }\end{array}$ & $\begin{array}{c}(2) \\
\text { Lntea }\end{array}$ & $\begin{array}{c}(3) \\
\text { Lnestablished }\end{array}$ & $\begin{array}{c}(4) \\
\text { Lnestablished }\end{array}$ \\
\hline Ln ratio top 4 deciles to bottom 4 deciles year 1820 & $-0.442^{* *}$ & & $-0.958^{* *}$ & \\
& $(0.203)$ & & $(0.394)$ & $-2.366^{* * *}$ \\
Ln Gini 1820 & & $-1.307^{* * *}$ & & $(0.899)$ \\
& & $(0.490)$ & & -0.047 \\
Political stability & $-0.153^{*}$ & $-0.149^{*}$ & -0.055 & $(0.107)$ \\
& $(0.090)$ & $(0.087)$ & $(0.110)$ & -0.059 \\
Control corruption & 0.034 & 0.022 & -0.053 & $(0.142)$ \\
& $(0.081)$ & $(0.077)$ & $(0.140)$ & 0.016 \\
Number procedure start business & 0.009 & 0.008 & 0.018 & $(0.018)$ \\
& $(0.012)$ & $(0.012)$ & $(0.018)$ & $0.002^{* *}$ \\
Access to credit & 0.000 & 0.000 & $0.001^{*}$ & $(0.001)$ \\
& $(0.001)$ & $(0.001)$ & $(0.001)$ & -0.000 \\
GNI per capita 2000 & $-0.000^{*}$ & $-0.000^{*}$ & -0.000 & $(0.000)$ \\
& $(0.000)$ & $(0.000)$ & $(0.000)$ & \\
\%Personally knows someone who started a & & & & $0.754^{*}$ \\
business 2 years ago & $1.501^{* * *}$ & $1.475^{* * *}$ & $0.771^{* *}$ & $(0.393)$ \\
& $(0.300)$ & $(0.301)$ & $(0.384)$ & 0.194 \\
\% Post-secondary education & $0.506^{* *}$ & $0.524^{* *}$ & 0.170 & $(0.262)$ \\
& $(0.237)$ & $(0.237)$ & $(0.262)$ & Yes \\
Region fixed effects & Yes & Yes & Yes & Yes \\
Year fixed effects & Yes & Yes & Yes & 217 \\
Observations & 217 & 217 & 217 & 52 \\
Number of countries & 52 & 52 & 52 & \\
\hline
\end{tabular}

Notes: Robust standard errors in parentheses. Significance levels *** $p<0.01, * * p<0.05, * p<0.1$ 
Table A.5. Entrepreneurial activity, first stage of instrumental variable regressions with panel random effects

\begin{tabular}{|c|c|c|c|c|c|c|c|c|}
\hline \multirow{3}{*}{ Instrumented variables: } & \multirow[t]{2}{*}{$(1)$} & \multirow{2}{*}{\multicolumn{2}{|c|}{$\begin{array}{l}(2) \quad(3) \\
\text { First stage } \text { TEA }\end{array}$}} & \multirow[t]{2}{*}{ (4) } & \multirow[t]{2}{*}{ (5) } & \multirow{2}{*}{\multicolumn{2}{|c|}{$\begin{array}{cc}(6) & (7) \\
\text { First stage Established }\end{array}$}} & \multirow[t]{2}{*}{ (8) } \\
\hline & & & & & & & & \\
\hline & $\begin{array}{l}\text { Political } \\
\text { stability }\end{array}$ & $\begin{array}{l}\text { Control } \\
\text { corruption }\end{array}$ & $\begin{array}{c}\text { Number } \\
\text { procedure } \\
\text { start }\end{array}$ & $\begin{array}{l}\text { Access to } \\
\text { credit }\end{array}$ & $\begin{array}{l}\text { Political } \\
\text { stability }\end{array}$ & $\begin{array}{c}\text { Control } \\
\text { corruption }\end{array}$ & $\begin{array}{c}\text { Number } \\
\text { procedure } \\
\text { start }\end{array}$ & $\begin{array}{l}\text { Access to } \\
\text { credit }\end{array}$ \\
\hline Ln ratio 9 to 1 income share for year 1820 & 0.26 & -0.255 & $-6.606 * *$ & $47.897^{*}$ & 0.26 & -0.255 & $-6.606 * * *$ & $47.897^{*}$ \\
\hline & $(0.512)$ & $(0.393)$ & $(2.349)$ & $(27.387)$ & $(0.512)$ & $(0.393)$ & $(2.349)$ & $(27.387)$ \\
\hline \multicolumn{9}{|l|}{ \%Personally knows someone who started a } \\
\hline \multirow[t]{2}{*}{ business 2 years ago } & 1.733 & 0.644 & -3.461 & $-114.394^{*}$ & 1.733 & 0.644 & -3.461 & $-114.394 *$ \\
\hline & $(1.206)$ & $(0.925)$ & $(5.53)$ & $(64.477)$ & $(1.206)$ & $(0.925)$ & $(5.53)$ & $(64.477)$ \\
\hline \multirow[t]{2}{*}{ GNI per capita 2000} & 0.000 & 0.000 & 0.000 & 0.000 & 0.000 & $0.000^{*}$ & 0.000 & 0.000 \\
\hline & $(0.000)$ & $(0.000)$ & $(0.000)$ & $(0.000)$ & $(0.000)$ & $(0.000)$ & $(0.000)$ & $(0.001)$ \\
\hline \multirow[t]{2}{*}{$\%$ Post-secondary education } & 0.613 & -0.425 & -7.413 & 92.322 & 0.613 & -0.425 & -7.413 & 92.322 \\
\hline & (1.113) & $(0.854)$ & (5.104) & $(59.507)$ & $(1.113)$ & $(0.854)$ & (5.104) & (59.507) \\
\hline \multirow[t]{2}{*}{ Journalist killed CPJ } & 10.587 & 9.187 & -51.408 & 440.062 & 10.587 & 9.187 & -51.408 & 440.062 \\
\hline & (9.264) & (7.104) & $(42.476)$ & $(495.201)$ & (9.264) & (7.104) & $(42.476)$ & $(495.201)$ \\
\hline \multirow[t]{2}{*}{ Blood pressure male } & $0.114^{* * *}$ & $0.077^{* *}$ & -0.194 & $6.919^{* * *}$ & $0.114^{* * *}$ & $0.077^{* *}$ & -0.194 & $6.919 * * *$ \\
\hline & $(0.036)$ & $(0.027)$ & $(0.163)$ & $(1.905)$ & $(0.036)$ & $(0.027)$ & $(0.163)$ & $(1.905)$ \\
\hline \multirow[t]{2}{*}{ Fixed telephone subscriptions (per 100 people) } & $0.054^{* *}$ & $0.06 * * *$ & -0.023 & $-2.226^{*}$ & $0.054 * *$ & $0.06^{* * *}$ & -0.023 & $-2.226^{*}$ \\
\hline & $(0.024)$ & $(0.018)$ & $(0.109)$ & $(1.266)$ & $(0.024)$ & $(0.018)$ & (0.109) & $(1.266)$ \\
\hline \multirow[t]{2}{*}{ European settler mortality Acemoglu et al. } & 0.001 & 0.00 & -0.002 & $-0.196 * *$ & 0.001 & 0.00 & -0.002 & $-0.196 * *$ \\
\hline & $(0.001)$ & $(0.001)$ & $(0.005)$ & $(0.062)$ & $(0.001)$ & $(0.001)$ & $(0.005)$ & $(0.062)$ \\
\hline \multicolumn{9}{|c|}{ Colonies (never colonized by Western oversea reference) } \\
\hline \multirow[t]{2}{*}{ Spanish Colony } & $-17.163 * * *$ & $-10.449 * *$ & $45.002^{*}$ & $-784.55^{* * *}$ & $-17.163 * * *$ & $-10.449 * *$ & $45.002^{*}$ & $-784.55^{* * *}$ \\
\hline & $(5.323)$ & $(4.082)$ & (24.409) & $(284.576)$ & $(5.323)$ & $(4.082)$ & $(24.409)$ & $(284.576)$ \\
\hline \multirow[t]{2}{*}{ British Colony } & $-17.159 * *$ & $-10.341^{* *}$ & $51.266 * *$ & $-799.682 * * *$ & $-17.159 * * *$ & $-10.341^{* *}$ & $51.266 * *$ & $-799.682 * * *$ \\
\hline & $(5.456)$ & $(4.184)$ & $(25.017)$ & $(291.664)$ & $(5.456)$ & $(4.184)$ & $(25.017)$ & (291.664) \\
\hline \multirow[t]{2}{*}{ French Colony } & $-17.459^{* *}$ & $-10.584^{* *}$ & $52.226 * *$ & $-863.197 * * *$ & $-17.459 * * *$ & $-10.584^{* *}$ & $52.226 * *$ & $-863.197 * * *$ \\
\hline & $(5.391)$ & $(4.134)$ & $(24.717)$ & $(288.161)$ & (5.391) & $(4.134)$ & $(24.717)$ & $(288.161)$ \\
\hline \multirow[t]{2}{*}{ Blood pressure*Journalists killed CPJ } & -0.086 & -0.073 & 0.402 & -3.428 & -0.086 & -0.073 & 0.402 & -3.428 \\
\hline & $(0.073)$ & $(0.056)$ & (0.333) & (3.878) & $(0.073)$ & $(0.056)$ & (0.333) & (3.878) \\
\hline Region fixed effects & Yes & Yes & Yes & Yes & Yes & Yes & Yes & Yes \\
\hline Year fixed effects & Yes & Yes & Yes & Yes & Yes & Yes & Yes & Yes \\
\hline Observations & 67 & 67 & 67 & 67 & 67 & 67 & 67 & 67 \\
\hline Number of countries & 21 & 21 & 21 & 21 & 21 & 21 & 21 & 21 \\
\hline
\end{tabular}

Notes: Robust standard errors in parentheses. Significance levels $* * * p<0.01, * * p<0.05, * p<0.1$

Instrumented variables: political stability, control corruption, number procedures start business, access to credit. Excluded instruments: Journalists killed, blood pressure, fixed telephone subscriptions, European settler mortality, whether former colonies, interaction between blood pressure and journalists killed. 
Table A.6. Entrepreneurial activity, second stage of instrumental variable regressions with panel random effects

\begin{tabular}{|c|c|c|}
\hline & $\begin{array}{c}(1) \\
\text { Lntea }\end{array}$ & $\begin{array}{c}\text { (2) } \\
\text { Lnestablished }\end{array}$ \\
\hline \multirow[t]{2}{*}{ Ln ratio 9 to 1 income share for year 1820} & $-1.439 *$ & $-2.404^{* * *}$ \\
\hline & $(0.765)$ & $(0.767)$ \\
\hline \multirow[t]{2}{*}{ Political stability } & 0.224 & -0.113 \\
\hline & $(0.612)$ & (0.614) \\
\hline \multirow[t]{2}{*}{ Control corruption } & -1.020 & -0.462 \\
\hline & $(0.772)$ & $(0.775)$ \\
\hline \multirow[t]{2}{*}{ Number procedure start business } & -0.112 & -0.181 \\
\hline & $(0.0953)$ & $(0.1156)$ \\
\hline \multirow[t]{2}{*}{ Access to credit } & -0.00326 & -0.00677 \\
\hline & $(0.00417)$ & $(0.00418)$ \\
\hline \multirow[t]{2}{*}{ GNI per capita 2000} & $3.76 e-05$ & $-4.68 \mathrm{e}-05$ \\
\hline & $(4.29 \mathrm{e}-05)$ & $(4.30 \mathrm{e}-05)$ \\
\hline \multicolumn{3}{|l|}{ \%Personally knows someone who started a } \\
\hline \multirow[t]{2}{*}{ business 2 years ago } & -0.226 & $-2.766^{*}$ \\
\hline & $(1.510)$ & $(1.515)$ \\
\hline \multirow[t]{2}{*}{$\%$ Post-secondary education } & -0.960 & -0.279 \\
\hline & (1.339) & $(1.343)$ \\
\hline Region fixed effects & Yes & Yes \\
\hline Year fixed effects & Yes & Yes \\
\hline Observations & 67 & 67 \\
\hline Number of countries & 21 & 21 \\
\hline Anderson-Rubin Wald Joint test & $91.16 * * *$ & $52.739 * * *$ \\
\hline Sargan statistic & 4.021 & 3.394 \\
\hline Endogeneity test Chi2 & $22.74 *$ & 5.00 \\
\hline
\end{tabular}

Notes: Robust standard errors in parentheses. Significance levels $* * * p<0.01, * * p<0.05, * p<0.1$ Instrumented variables: political stability, control corruption, number procedures start business, access to credit. Excluded instruments: Journalists killed, blood pressure, fixed telephone subscriptions, European settler mortality, whether former colonies, interaction between blood pressure and journalists killed. 